\title{
Jeḷena Groma
}

\section{CRIMINAL PROCEDURAL COMPULSORY MEASURES: THE TOPICAL ISSUES AND LEGAL REGULATION ENHANCEMENT PROSPECTS}

Summary of Doctoral Thesis for obtaining the degree of a Doctor of Law Speciality - Law Subfield - Criminal Law 
Jel̦ena Groma

\section{CRIMINAL PROCEDURAL COMPULSORY MEASURES: THE TOPICAL ISSUES AND LEGAL REGULATION ENHANCEMENT PROSPECTS}

Summary of Doctoral Thesis

for obtaining the degree of a Doctor of Law

Speciality - Law

Subfield - Criminal Law

Riga, 2015 
The Doctoral Thesis was carried out at Riga Stradins University

Scientific supervisor:

Dr. iur., Professor Sandra Kaija,

Riga Stradins University, Latvia

Official reviewers:

Dr. iur., Professor Vitolds Zahars,

Riga Stradins University, Latvia

Dr. iur., Associate Professor Jānis Teivāns-Treinovskis,

Daugavpils University, Latvia

Dr. habil. iur., Professor Viktoras Justickis,

Mykolas Romeris University, Lithuania

Defense of the doctoral thesis will take place during the public meeting of Riga Stradins University Promotion Council on 18 August 2015, at 14.00 in Hippocrates Lecture Hall, Dzirciema street 16, Rīga Stradin̄š University

The Doctoral Thesis is available at RSU Library and RSU homepage: www.rsu.lv

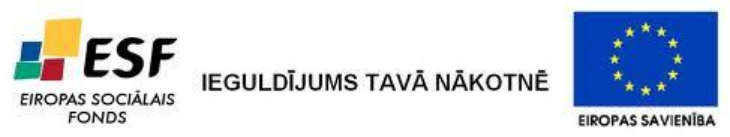

The thesis was elaborated with the financial support under the ESF project of

"Support for the Acquisition of Doctoral Study Programmes and Scientific

Degree at Riga Stradins University", agreement Nr. 2009/0147/1DP/1.1.2.1.2./09/IPIA/VIAA/009.

Secretary of the Promotion Council:

Dr. iur., Professor Sandra Kaija 


\section{CONTENTS}

1. THE OVERALL DESCRIPTION OF THE DOCTORAL THESIS .... 4

1.1. The topicality of the research........................................................ 4

1.2. The goal of the thesis .............................................................. 7

1.3. Objectives of the study ............................................................... 7

1.4. The novelty of the research........................................................ 8

1.5. Research questions ............................................................. 10

1.6. The object and the subject of the doctoral thesis ......................... 10

1.7. The methods of research implemented ....................................... 11

1.8. The approbation of the results of the doctoral thesis.................... 12

2. THE BRIEF SUMMARY OF THE DOCTORAL THESIS ................. 15

2.1. Criminal procedural compulsory measures, their general description and place in the state legal enforcement system.......... 15

2.2. The system of criminal procedural compulsory measures in Latvia

3. THE GUARANTEES OF THE OBSERVATION OF THE RIGHTS AND FREEDOMS OF A PERSON IN THE IMPLEMENTATION OF CRIMINAL PROCEDURAL COMPULSORY MEASURES . 50

3.1. The guarantees of a person in the implementation of criminal procedural compulsory measures

3.2. The prevention of torture and inhuman or degrading treatment and the observation of the rights of persons deprived of their liberty in the course of the implementation of criminal procedural compulsory measures

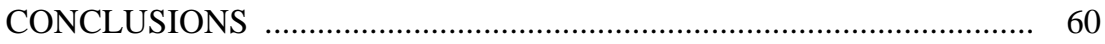

ACKNOWLEDGEMENTS ................................................................ 71

LIST OF LITERATURE AND SOURCES .............................................. 72 


\section{THE OVERALL DESCRIPTION OF THE DOCTORAL THESIS}

\subsection{The topicality of the research}

The development of the Latvian state aimed at the democratic European social model suggests the supreme governance of law, political legitimacy as well as respect for and observance of human rights, fundamental freedoms and legal interests. Professor of Criminology A. Vilks points out that crime and other violations of law disrupt social order, thus causing irreparable harm to both individual members of the public, to the society, as well as to the civilization as a whole. Therefore, since the very moment when humanity became aware of the influence and consequences of such deviations from the generally accepted norms, particular mechanisms and forms were elaborated for protection against criminal action as well as for prevention and deterrence thereof ${ }^{1}$. Thus, efficient crime prevention is the duty of every state, and law enforcement bodies are assigned the responsibility to appropriately (that is, by means of a criminal procedure) verify any allegations of a violation. For this purpose bodies of state administration are supposed to examine the allegations raised as well as make the pivotal decision concerning the guilt or innocence of a particular person in accordance with the legislation and, if it appears necessary, to administer proper punishment. Professor A. Meikalisa describes criminal procedure as a legal process in the course of which a legally correct and fair decision has to be made observing the interests and needs of both the complainant and the perpetrator as well as those of the society ${ }^{2}$.

\footnotetext{
${ }^{1}$ Vilks A. Krimināltiesiskā politika: diskursa analīze un attīstības perspektīvas. Rīga, Drukātava, 2013, 5. lpp.

2 Meikališa Ā. Pārskats par kriminālprocesa attīstību Latvijā 2005.-2011. gadā // LZA Vēstis, 2012/66: 76.-80. lpp.
} 
There is a tendency for paying even more attention to human rights and the observation of those as a criterion of the development of state democracy and an important element of the legal basis of the state. This reflects the democratic priority values of the socio-political order and forms an equitable internally conformal core value system representative of such order ${ }^{3}$.

Having gained a new meaning, human rights have been institutionalized in a set of new social forms and have thus become the crystallization point of the contemporary international community ${ }^{4}$. These are clear, precise and specific legal regulations that are incorporated in international documents, the Constitution of the Republic of Latvia (Satversme) and the legal acts. Notwithstanding this, not all human rights are utterly free from restriction, as in certain circumstances some of those may be limited by the state, in case if such limitations are established by law, have a legitimate purpose and are adequate.

The enforcement mechanism of any state is formed with a body of compulsory measures with compulsory measures of criminal procedure being part of that and serving as an indispensable tool in achieving the principal goal of a criminal procedure ${ }^{5}$. This tool, however, is supposed to function in compliance with procedural guarantees. The compulsory measures in criminal procedure including measures of suppression are only acceptable under such circumstances when their implementation is strictly necessary, hence a civilized community cannot permit the extension of state coercive practices and their provisions ${ }^{6}$. Criminal procedure has a prominent compulsory nature, therefore

${ }^{3}$ Ziemele I. (red.) Cilvēktiesības pasaulē un Latvijā. Izglîtības soḷi, Rīga, 2000, lpp. 409.

${ }^{4}$ Kēnigs M. Cilvēktiesības. Rīga, TNA, 2010., 41. lpp.

${ }^{5}$ Meikališa $\bar{A}$. Drošības līdzekḷu kriminālprocesuālā reglamentācija Latvijas likumdošanā. Rīga, 1995, 5. lpp.

${ }^{6}$ Стецовский Ю.И. Концепця судебной реформы и проблемы конституционной законности в уголовном судопроизводстве // Государство и право, 1993; (9): стр. 106. 
it is essential to ascertain that in the course or the procedure fundamental human rights, freedoms are interests are observed ${ }^{7}$.

Criminal Procedure Law (CPL) that came into force on October 1, 2005, had been elaborated in a gradual manner. The concepts of CPL had transformed in accordance with the necessities of the times, working groups elaborating the law had changed, the understanding of, as well as the approach to, the very essence, principles and structure of criminal procedure had altered. This legal act was elaborated for the purpose of creating the opportunity for the law enforcement agencies of Latvia to operate in compliance with the provisions of criminal justice set forth by the Council of Europe and the European Union (EU), making use of internationally recognized contemporary solutions in the field of criminal procedure relations, preventing the accumulation of pending cases in pre-trial investigation institutions and courts as well as for the purpose of accelerating excessively long court proceedings and eradicating grounds for complaints about human rights abuse ${ }^{8}$.

One of the characteristics of the development of the EU is, undoubtedly, the transformation of its legal system. On the national level this transformation suggests the improvement and harmonization of the legislative acts of the EU member states (including those of Latvia). In accordance with sections 2 and 29 of the EU agreement ${ }^{9}$, the purpose of the EU - that is to ensure a high degree of protection for EU citizens in the sphere of freedom, safety and legitimacy - has to be achieved by preventing and deterring organized crime and other types thereof. The Treaty of Lisbon indicates that the EU is based on fundamental

${ }^{7}$ Meikališa Ā. Drošības līdzekḷu kriminālprocesuālā reglamentācija Latvijas likumdošanā. Rīga, 1995, 5. lpp.

${ }^{8}$ Kaija S. Kriminālprocesa tiesību transformācija Latvijā. Transformācijas process ties̄ibās, reǵionālajā ekonomikā un ekonomiskajā politikā. Rīga, 2013, 39.-47. lpp.

9 Līguma par Eiropas Savienību konsolidētā versija. Eiropas Savienības Oficiālais Vēstnesis, C 83/13, 30.03.2010., erv/LexUriServ.do?uri=OJ:C:2010:083:0047: 020:lv:PDF 
values that suggest human respect, freedom, democracy, equality, legitimacy and human rights, and the values are shared by all the EU member states. After the expiry of the Stockholm Programme Latvia has to tangibly and efficiently continue improving and facilitating the enactment of the existing legislative acts as well as reviewing framework decisions made before the enforcement of the Treaty of Lisbon ${ }^{10}$.

Consequently, the relevance and topicality of the selected theme of the thesis is conditioned by the necessity of analyzing the provisions set forth by the Council of Europe and the EU as well as the contemporarily recognized solutions in the sphere of criminal procedural relations. The sphere of interest of the author of the present doctoral thesis embraces determining the essential issues in the legal regulation of the compulsory measures in criminal procedure and elaborating suggestions for its enhancement.

\subsection{The goal of the thesis}

The goal of the thesis is to analyze the legal regulation of criminal procedural compulsory measures and to identify attendant problems, as well as to develop suggestions for further enhancement of the national legal norms.

\subsection{Objectives of the study}

The thesis has the following objectives:

- Describing coercion in criminal procedure as a component of the state law enforcement system and scrutinizing its significance in the exertion of state authority;

10 Informatīvais ziņojums par 2014. gada 23.-24. janvārī neformālajā Eiropas Savienības Tieslietu un iekšlietu ministru padomē izskatāmajiem Tieslietu ministrijas kompetencē esošajiem jautājumiem. www.mk.gov.lv/doc/2005/ TMZino_200114_JHAC.127.doc 
- Determining the essence of the compulsory measures in criminal procedure, their fundamental framework, legal nature and social value;

- Characterizing the compulsory measures in criminal procedure as a systematic phenomenon; estimating the legal regulation of coercive measures as specified in CPL, determining the goal of their application and their peculiar features and problematic issues as well as estimating the development prospects of legal regulation; elaborating suggestions for further enhancement of the national legal norms;

- Analyzing the subject matter of transnational constitutional and criminal procedural directives on human rights and fundamental freedoms; scrutinizing the restriction of rights by means of criminal procedural compulsory measures;

- Investigating the criteria for human rights restriction in connection with the implementation of compulsory measures in criminal procedure basing on the judicial practice of the European Court of Human Rights (ECHR);

- Investigating the international tools binding on the member states implemented for protection of human rights and fundamental freedoms; investigating the recommendations incorporated in the European Convention for the Prevention of Torture and Inhuman or Degrading Treatment or Punishment.

\subsection{The novelty of the research}

The analysis of juridical literature indicates that previous juridical publications focused on investigating the compulsory measures in criminal procedure and attendant problems and incorporated the analysis of the issues of 
legal regulation and specific legal norms. However, the problematic issues of the legal regulation of criminal procedural compulsory measures and its improvement tendency were not so explicitly examined. The analysis of the compulsory measures in criminal procedure in the context of the theory of value has novelty attributes. Even the institution of investigating judge has not been examined very close heretofore ${ }^{11}$, notwithstanding the fact that, in comparison with the historically determined functions of the investigating magistrate, his contemporary authority embraces the essential duty of controlling the observation of human rights and fundamental freedoms in the course of criminal procedure. Being fully aware of the fact that the range of issues embraced by the theme of the present research is extremely wide, the author of the doctoral thesis aims to only investigate the legal regulation (and the opportunities of enhancement thereof) of criminal procedural compulsory measures set forth by CPL, without aiming to perform an all-encompassing and complete analysis of the system and classification of the types of criminal procedure compulsory measures. The essential contribution of the present thesis is the comprehensive approach towards the assessment of the legal regulation of compulsory measures in criminal procedure also incorporating the compulsory measures implemented in international cooperation in the field of criminal procedure. The thesis thoroughly analyzes and provides the summary of implications arising from the judicial practice of the ECHR as well as summarizes and analyzes the indispensable components of the EU system of human rights protection, in particular, the recommendations concerning the implementation of compulsory measures in criminal procedure as enshrined in

11 Skat. piemēram, Gailīte V. Izmeklēšanas tiesneša kompetence. // Jurista Vārds, 2006, Nr. 7(410); Kūtris G. Izmeklēšanas tiesneši - jauns institūts kriminālprocesā. // Jurista Vārds. 2006, Nr. 2(405), 1pp. 1-4.; Dundure L. Izmeklēšanas tiesnesis Latvijā. // Jurista Vārds, 2012, 17/18(716/717): 26.-31. lpp. 
the European Convention for the Prevention of Torture and Inhuman or Degrading Treatment or Punishment and attendant issues.

\subsection{Research questions}

Criminal procedural compulsory measures are indispensable to the contemporary law enforcement mechanism, and they have to comply with human rights and legal interest guarantees in criminal procedure. The interaction of peculiarities of human rights protection standards and those of the mechanism of enforcement of the compulsory measures in criminal procedure as enshrined in the national legislation outlines the further development of criminal science.

\subsection{The object and the subject of the doctoral thesis}

The object of the doctoral thesis is the connection between criminal procedural relations and the implementation of criminal procedural compulsory measures in the course of criminal procedure.

The subject of the doctoral thesis is the body of legal sources determining the compulsory measures in criminal procedure. In compliance with the recommendations of D. Iljanova, the legal sources mentioned above are classified as either those falling under the category of independent sources of law in the legal system of Latvia (specifically - legislative acts, customary law and general legal principles) or those falling under the category of auxiliary sources of law with legal practice (judicature), legal doctrine and legislative act drafting materials ${ }^{12}$.

12 Iljjanova D. Vispārējo tiesību principu nozīme un piemērošana. Rīga, Nodibinājums Ratio iuris, 2005, 57.-58.lpp. 


\subsection{The methods of research implemented}

In the course of elaborating the present doctoral thesis the following research methods were implemented: the historical method, the analytical method, the comparative method, the inductive approach, the deductive approach and the modeling method.

The historical method was implemented in the description of the development of the national legal regulation of compulsory measures in criminal procedure. The analytical method was applied in scrutinizing acts of international and national legislation and legal practice materials. Analysis is what underlies the assessment, implications and suggestions presented in the thesis. The comparative method of research was used for the purpose of elucidating and assessing the interaction of the institute of criminal procedural compulsory measures with the legal system as a whole. The method of scientific induction was used in order to draw general conclusions and establish connections; the deductive approach, however, was applied in order to logically streamline as well as to theoretically interpret the empirical findings. The modeling method was used in the constructing of situational models connected with the implementation of compulsory measures in criminal procedure.

The interpretation of legal norms was carried out implementing the grammatical, historical, systematic and teleological interpretation methods, which means that 1) the grammatical (philological) interpretation method was used to elicit the essence of legal norms from the linguistic perspective; 2) the historical interpretation method was used in the process of elucidating the essence of the legal norm taking into consideration the circumstances underlying its elaboration; 3) the systematic method of interpretation was applied in the course of elucidating the essence of the legal norm as related to other legal norms; 4) the teleological method of interpretation (that of the essence and purpose) was used in elucidating the essence of the legal norm as 
based on a feasible and fair purpose to be achieved with the aforementioned legal norm.

The dissertation embraces international and national sources of law connected with criminal procedural enforcement, specialized literature related to the theme of the present research, the legal practice of the ECHR as well as statistical data. The theoretical basis of the research is formed with the information obtained from scientific papers in criminal law, criminal procedure, legal theory, etc. supplemented by scientific implications in the field of human rights, legal axiology and legal conflictology. In its turn, the empirical basis of the dissertation is constituted of the information connected with the topic of the research as reflected in the judicature of the ECHR, that of the courts of the Republic of Latvia and other legal practice materials, statistical sources as well as the experience of the author obtained in the course of conducting prejudicial inquiry.

The thesis consists of 222 pages and includes the introduction, three chapters and the conclusion constituted of implications and suggestions. The bibliography comprises the list of 568 sources in six languages.

\subsection{The approbation of the results of the doctoral thesis}

Scientific publications related to the theme of the thesis:

1. Izmeklēšanas tiesneša institūts kriminālprocesuālo piespiedu līdzekḷu aspektā (līdzautore prof. S. Kazaka) // Administratīvā un Kriminālā Justīcija, 1(58)/2012.g., 10.-15. lpp., ISSN 1407-2971.

2. Piespiedu līdzekḷu ietekme uz konflikta risināšanu kriminālprocesā (līdzautore prof. S. Kazaka) // Administratīvā un Kriminālā Justīcija, 2(59)/2012.g., 24.-30. 1pp., ISSN 1407-2971.

3. Kriminālprocesuālie piespiedu līdzekḷi tiesību aksiolog̣ijas kontekstā // Administratīvā un Kriminālā Justīcija, 1(62)/2013.g., 35.-41.lpp., ISSN 1407-2971. 
4. Kriminālprocesuālo piespiedu līdzekḷu institūta attīstība Latvijā: tendences un perspektīvas. Rakstu krājums "Transformācijas process tiesībās, reǵionālajā ekonomikā un ekonomiskajā politikā”, Rīga, 2013, 188.-195.lpp., ISBN 978-9984-47-076-4.

5. Kriminālprocesuālo piespiedu līdzekļu institūts tiesību sociologijas skatījumā // RSU Zinātnisko rakstu krājums „Zinātniskie raksti: 2012. gada Sociālo zinātṇu nozares pētnieciskā darba publikācijas", Tiesību sadaļa, Rīga, 2013, 108.-112.lpp., ISBN 978-9984-793-44-3, ISSN 1407-9453.

6. Ar brīvības atņemšanu nesaistīto drošības līdzekḷlu tiesiskā regulējuma pilnveidošana // RSU Zinātnisko rakstu krājums „Zinātniskie raksti: 2012. gada Sociālo zinātņu nozares pētnieciskā darba publikācijas”, Tiesību sadaḷa, Rīga, 2013, 113.-118.lpp., ISBN 978-9984-793-44-3, ISSN 1407-9453.

7. Overall human values in context of institute of criminal procedural compulsory measures $/ / 4^{\text {th }}$ International Interdisciplinary Scientific Conference SOCIETY, HEALTH, WELFARE. SHS Web of Conferences (online), included on Conference Proceedings Citation Index (Web of Science), DOAJ, Google Scholar, ISBN 978-2-75981639-2, 2014, Vol. 10, 1-6 pp.

8. Ar brīvības atņemšanu nesaistītie drošības līdzekḷi un to termiņi pirmstiesas kriminālprocesā // Izaicinājumu un iespēju laiks: problēmas, risinājumi, perspektīvas, materiālu krājums, Rēzekne, 2013, 297.-307. lpp., ISBN 978-9984-47-077-1.

9. Starptautiskā kriminālprocesuālā sadarbība Eiropas Savienības telpā // RSU Zinātnisko rakstu krājums „Zinātniskie raksti: 2013. gada Sociālo zinātņu nozares pētnieciskā darba publikācijas", Tiesību sadaļa, ISBN 978-9984-793-58-0, ISSN 1407-9453, Rīga, 2014, 35.44.lpp.

10. Izmainas kriminālprocesuālo drošības līdzekḷu tiesiskajā regulamentācijā // Administratīvā un Kriminālā Justīcija, 3(63)/2013.g., 23.-29. lpp., ISSN 1407-2971.

11. The European Arrest Warrant: Latvian Experience of Application (līdzautore prof. S. Kaija) // Mediterranean Journal of Social Sciences, 2013, Special Issue, Vol. 4, N.11, 310-315 pp. Iekḷauts EBSCOhost, EBSCO Publishing, Index Copernicus International, Ulrichsweb and other index/abstracting libraries, E-ISSN 2039-2117, ISSN 2039-9340. 
12. The European Arrest Warrant: Latvian Experience of Application (līdzautore prof. S. Kaija) // ICHSS 2013 Conference Proceedings 2013, Volume 6, 310-315 pp.

13. Kriminālprocesuālo piespiedu līdzekḷu piemērošana kriminālsodu politikas reformas ietekmē // II Starptautiskas zinātniski praktiskas konferences "Transformācijas process tiesībās, reǵionālajā ekonomikā un ekonomiskajā politikā: ekonomiski-politisko un tiesisko attiecību aktuālās problēmas" rakstu krājums, ISBN 9789984-47-096-2, Rīga, 2014, 188.-195. lpp.

14. Spīdzināšanas un necilvēcīgas rīcības prevencijas mijiedarbība ar personas, kurai kriminālprocesā ir liegta brīvība, tiesību ievērošanu // IV Starptautiskās jauno pētnieku un studentu zinātniski praktiskās konferences "Izaicinājumu un iespēju laiks: problēmas, risinājumi, perspektīvas" rakstu krājums, ISBN 978-9984-47-091-7, Rīga, 2014, 36.-41. lpp.

15. Guarantees of persons deprived of liberty in criminal procedure in the light of recommendations issued by the European Committee for the Prevention of Torture and Inhuman or Degrading Treatment of Punishment (lïdzautore prof. S. Kaija) // International Journal of Social Sciences, double-blind peer-reviewed journal included on Google Scholar, ProQuest, Ulrich's Periodicals, Open J-Gate, ResearchBib, Newjour-L, WorldCat, Electronic Journals Library, University of Regensburg and other index/abstracting libraries, ISSN 1804-980X (online), 2014, Vol. III (3), 1-11 pp.

The author of the doctoral thesis has presented the results of research at 5 international and 4 local conferences. 


\section{THE BRIEF SUMMARY OF THE DOCTORAL THESIS}

\subsection{Criminal procedural compulsory measures, their general description and place in the state legal enforcement system}

The idea of the need for a novel, contemporary, prompt and costefficient criminal procedure arose simultaneously with the declaration of the independence of Latvia and it was expressed by many theoreticians and practitioners in the sphere of criminal procedure ${ }^{13}$. As a result, in the course of elaboration of CPL concept, feasible imperative requirements constituted of different aspects were developed, specifically, the simplification and acceleration of the procedure, priority setting and relevant allocation of resources as well as the proportional restriction of human rights. Primarily, the modernization of criminal procedure is understood as the necessity to accelerate the process of criminal procedure, thus reducing the time span between the commission of a crime and the legal conclusion of the criminal procedure. Secondarily, the modernization suggests streamlining criminal procedure by simplifying its process eliminating the legally ungrounded elements unnecessarily complicating the work of the person directing the criminal proceedings. Thirdly, the modernization is understood as making criminal procedure more resource-efficient, saving (to the extent possible) time, human and financial resources. Fourthly, the modernization implies increasing the efficiency of criminal procedure by providing the opportunity insofar as possible to promptly carry out a set of comprehensive and evidentiarily productive investigative activities, in case of necessity introducing adequate novel measures relevant to the contemporary criminal situation simultaneously

13 Skrastiņš J. Par jauniem likuma pamatprincipiem // Jurista Vārds, 2001; (7). 
being aware of the necessity of the protection of human rights as one of the main indicators of the development of criminal procedure law ${ }^{14}$.

On October 1, 2005, as a result of sustained effort, the Criminal Procedure Code of Latvia was substituted for CPL introducing a number of developments and alterations to the general provisions in the sphere of pretrial criminal and court proceedings ${ }^{15}$. Since the very moment it came into force, CPL has been characterized by sustainable improvement. I.Reine, a lawyer, emphasizes the fact that the law is supposed to define criteria, restrictions and exceptions that are applicable to specific situations ${ }^{16}$. Emerging trends in the regulation of relations in criminal procedure on the international level and abroad have not only given rise to the necessity of examining the existing opportunities of development, but also have laid the groundwork for forecasting, predictive modeling and estimation of future development opportunities ${ }^{17}$. Besides, the emerging trends have predetermined the need for rethinking the traditional concept of human rights and the interpretation of many of the common principles of criminal procedure as well as the need for continuing the simplification of criminal procedure and harmonizing the directives of the international documents binding upon the Republic of Latvia with the national legal norms ${ }^{18}$.

On October 19, 1992 Recommendation No.R (92)16 on the European Rules on Community Sanctions and Measures was adopted by Committee of

14 Strada - Rozenberga K. Kriminālprocesa vienkāršošana: izpratne, tendences, problēmas // Jurista Vārds, 2004; (30).

15 Krimināltiesības - attīstības tendences Eiropas un nacionālajā tiesībās, attiecības starp I un III pīlāru, ieviešanas metožu labākā prakse. Rīga, 2009.//http:www. tm.gov.lv/documents/petijumi/kriminaltiesibas2.doc

16 Intervija: Nedēl̦as jurists - Inga Reine, Jurista Vārds, 2010, Nr. 24, 2. lpp.

17 Meikališa Ā. Pārskats par kriminālprocesa attīstību Latvijā 2005.-2011. gadā // LZA Vēstis, 2012/66: 76.-80. lpp.

18 Kaija S. Aktuālākie transformācijas virzieni kriminālprocesa tiesību jomā Latvijā // Administratīvā un Kriminālā Justīcija, 2013, Nr.1, 15.-20. lpp. 
Ministers of the Council of Europe ${ }^{19}$, that summarized and provided the layout of the principles recommended for consideration in national legal acts and practice. Firstly, establishing a set of standards to enable national legislators and the practitioners concerned (deciding authorities and authorities responsible for the implementation) to provide a just and effective application of community sanctions and measures. This application must aspire to maintain a necessary and desirable balance between, on the one hand, the need to protect society both in the sense of the maintenance of legal order as well as the application of norms providing for reparation of the harm caused to victims, and, on the other hand, the essential recognition of the needs of the offender having regard to his social adjustment. Then, furnishing member states with basic criteria so that the creation and use of community sanctions and measures may be combined with guarantees against the danger that the fundamental human rights of offenders subject to such sanctions and measures are curtailed. Further, proposing clear rules of conduct to staff responsible for the implementation of community sanctions and measures and to all those in the community who are involved in this field in order to ensure that this implementation is in conformity with any conditions and obligations imposed. Besides, it is emphasized that no community sanction or measure restricting the civil or political rights of an offender shall be created or imposed if it is contrary to the norms accepted by the international community concerning human rights and fundamental freedoms. Moreover, a community sanction or measure shall never involve medical or psychological treatment or procedures which are not in conformity with internationally adopted ethical standards. Also, the nature, content and methods of implementation of a community

19 Recommendation No.R(92) 16 of the Committee of Ministers to member states on the European rules on community sanctions and measures// http://pjpeu.coe.int/documents/3983922/6970334/CMRec+(92)+16+on+the+European+rules +on+community+sanctions+and+measures.pdf/01647732-1cf7-4ea8-88ba$2 \mathrm{c} 041 \mathrm{bc} 3 \mathrm{f} 5 \mathrm{~d} 6$ 
sanction or measure shall not involve undue risk of any physical or mental injury.

Then, Recommendation Rec (2000) 22 to member states on Improving the Implementation of the European Rules on Community Sanctions and Measures $^{20}$, adopted by the Committee of Ministers of the Council of Europe adopted on 29 November 2000 asserts that important developments and changing practice in the area of community sanctions and measures and the issues identified by the member states call for additional explanations and interpretations of certain provisions contained in the European Rules. Member states are recommended to expand the range of suitably varied community sanctions and measures as well as to provide alternatives for pre-trial detention such as requiring a suspected offender to reside at a specified address and to be supervised or restricting the freedom of movement by means of, for example, electronic monitoring.

The development of Latvia as that of a judicial society is characterized by the sustained enhancement of its state structure including the improvement of compulsory measures in criminal procedure achieved through incorporating international legal acts into the national legal system, thus strengthening procedural safeguards. The concept of a jural society results from a continuous political practice and the evolution of thinking. The core principle of the jural society is the commitment to the establishment of justice in terms of both its procedural and material aspect. In order to ensure the implementation of the principle of the rule of law, it is necessary to resolve the conflict between legal stability and justice, which is exactly the purpose legal norms serve. In the

20 Recommendation $\operatorname{Rec}(2000) 22$ of the Committee of Ministers to member states on improving the implementation of the European rules on community sanctions and measures (Adopted by the Committee of Ministers on 29 November 2000 at the $731^{\text {st }}$ meeting of the Ministers Deputies) // https://wcd.coe.int/com. instranet.InstraServlet?command=com.instranet.CmdBlobGet\&InstranetImage $=534$ $373 \&$ SecMode $=1 \&$ DocId $=377888 \&$ Usage $=2$ 
event of legal norms failing to achieve the set purpose of comprehensively resolving the conflict between justice and legal trust, the norms prove to be inefficient. The existence of a judicial society is comprised of two major components - human freedom and the protection of human rights as well as the restriction of authority of the state ${ }^{21}$. The commitment of the society and law enforcement officials of Latvia to the contemporary democratic European state model is unalterable. This serves as the evidence of compliance of Latvian social and political ideas with those of Europe and, more generally, with western political and legal philosophy as well as the historical experience ${ }^{22}$. The existence of a democratic state is impossible without coercion which rests on power and reflects the interests of the state authority ${ }^{23}$. Coercion is an indispensable element of any community structure; it affects the behavior of community members thus safeguarding legal order. According to its functional characteristics, it is classified in connection with 1) the type of impact (personal, organizational or property); 2) the legal meaning of the action (sanctions and supplementary preventive measures); 3) law enforcement techniques (penal measures, remedial action and measures of restraint); 4) the authorities applying law enforcement measures (the court and law enforcement bodies); 5) basis for coercion (criminal procedural, administrative, disciplinary basis as well as that of human rights $)^{24}$.

21 Рогов А.П. Правовое государство и государственное принуждение. Известия Саратовского университета, 2011, Т. II. Сер. Экономика. Управление. Право. Вып. 2, стр.104-108.

22 Levits E. Latvijas tiesību sistēmas attīstības iezīmes uz XXI gadsimta sliekšņa. Grām.: Latvijas tiesību vēsture (1914-2000). Prof. Dr.iur. D.A. Lēbera redakcijā. Rīga: LU žurnāla „Latvijas Vēsture” fonds, 2000., 493.lpp.

23 Kegley, J.A.K.. Re-assessing Compulsion and Persuation in Democracy via a New Framework // J. A. K. Kegley and K. P. Skowronski (Eds.), Persuasion and Compulsion in Democracy. - 2013, - Lexington Books, Plymouth, UK, 1-18.

24 Шевелева С.В. Виды мер правового принуждения. Пробелы в российском законодательстве, 2010, 3, стр.156 
Coercion is connected with a considerable restriction of human constitutional rights and fundamental freedoms. Criminal procedural coercion is characterized by certain actions of a specific nature taken by authorized officials in relation to the participants of a criminal procedure for the purpose of ensuring legal order. The restriction of human rights and fundamental freedoms in the course of criminal proceedings is exclusively admissible in accordance with the procedure laid out in law, considering its feasibility and legitimacy guarantees. The interaction of peculiarities of human rights protection standards and those of the mechanism of enforcement of the compulsory measures in criminal procedure as laid out in the national legislation determines the importance of investigating the institute of criminal procedural compulsory measures in the sphere of law enforcement ${ }^{25}$.

The range of core legal values includes such universal ones as justice, truth, public good, equality, honor, respect, etc. According to Prof. J.Melder, not only is legislation formed on the basis of the aforementioned values independent of the state, but it, as a matter of fact, determines the functioning of the latter, thus becoming the stabilizing factor of public life ${ }^{26}$. The essence of the universal human values is laid out in and determined by international legal norms that have a tendency towards becoming even more human-oriented ${ }^{27}$, as the constant development of international community calls for harmonizing individual and community rights with duties and restrictions ${ }^{28}$.

25 Мельников В. Ю. Обеспечение и защита прав человека при применении мер процессуального принуждения в досудебном производстве Российской Федерации // Москва, 2014, 552.

26 Melderis J. Vērtību teorijas un NBS pamatvērtības. Militāri zinātnisks žurnāls „Militārā zinātne”, 2011, 1, 141.

27 Смирнова И.Г. Права личности и аксиологическая сущность уголовного судопроизводства: постановка вопроса. Журнал Российское право в интернете. 2009 (05). www.rpi.msal.ru/prints

28 Андреева О.И. Пределы ограничения прав личности в уголовном процессе. Вестник Томского государственного университета. Право, 2012, № 358. 
As it follows from international legal norms and the Satversme ${ }^{29}$, human rights and freedoms are acknowledged and declared as fundamental values and they are subject to the hierarchy of individual-community-state. Restricting human rights and legal interests, public authority has to respect individual and community interests. Only fair regulation of criminal procedural relations can possibly justify the restriction of human rights and fundamental freedoms.

CPL determines such criminal procedure order that ensures the efficient implementation of the norms of Criminal Law as well as fair regulation of criminal procedural relations without unjustified intervention in the life of an individual. This means that the entire criminal procedure (including the implementation of criminal procedural compulsory measures) has to be carried out in compliance with the aforementioned order. The initiation of a criminal case provides the legal basis for procedural action including the implementation of criminal procedural compulsory measures. A criminal procedural compulsory measure may only be implemented when a legal situation has arisen that the legislator has determined as suitable for the implementation of the aforementioned compulsory measure. In the event of the absence of such a situation, the implementation of the criminal procedural compulsory measure is considered to be illegal. Therefore, the legislator does not limit himself to merely determining the grounds for the implementation of compulsory measures, but regulates the entire implementation procedure, thus guiding the law enforcer ensuring that the order of implementation of criminal procedural compulsory measures laid out in law is strictly observed.

http://cyberleninka.ru/article/n/predely-ogranicheniya-prav-lichnosti-v-ugolovnomprotsesse\#ixzz2hyK124IV

29 Latvijas Republikas Satversmes komentāri; VIII nodaḷa, Cilvēka pamattiesības, sagatavojis autoru kolektīvs R. Baloža vadība, Latvijas Vēstnesis, 2011. http://home.lu.lv/ rbalodis/Publikacijas/Constitutional_Law/Satv_Kom_ievads_R.B alodis.pdf 
The types of criminal procedural compulsory measures as well as the order of their implementation, reviewing, revocation and appeal are laid out in CPL. However the definition of the very concept of a criminal procedural compulsory measure was not included in the law. This problem was emphasized in 2006 in research work of professionals in criminal procedure ${ }^{30}$. One must suppose that the lack of specific definition of criminal procedural compulsory measures is probably connected with the existence of many types of procedural compulsory measures, with specific characteristics and objective inherent in every type.

The characteristic features of criminal procedural compulsory measures are as follows: criminal procedural compulsory measures may only be implemented by an authorized official; in the course of application of criminal procedural compulsory measures the restriction of constitutional human rights must be minimal and positively feasible; criminal procedural compulsory measures may only be applied in compliance with the order specified by CPL and only within the framework of criminal procedure; if a person under investigation resists the performance of procedural actions and hinders the progress thereof, or refuses to duly fulfill his or her procedural duties, the compulsory measures provided for in the Law for the ensuring of a concrete procedural action may be applied to such person; moreover, the application of criminal procedural compulsory measures may be based upon the presumption that the non-application of such measures may have adverse effect upon the progress of the criminal procedure. The application of any criminal procedural compulsory measure has to be proven feasible; in the course of application of criminal procedural compulsory measures the principle of proportionality has to be observed. The main purpose of legal coercion is ensuring public order; all

30 Meikališa Ā, Strada - Rozenberga K. Pārmaiṇu laiks kriminālprocesā. Procesuālie piespiedu līdzekḷi un sankcijas // Jurista Vārds, 2006; 26: lpp.11. 
the criminal procedural compulsory measures are measures ensuring the fulfillment of procedural duties. The application of criminal procedural compulsory measures is only connected with the restriction of civil rights and interests within the period of the criminal procedure, and the duration of the period of application is connected with the duration of the time span within which the grounds for application continue to exist. No criminal procedural compulsory measure in itself is a penalty ${ }^{31}$. The author would suggest an addition to the aforementioned multilateral listing, specifically, the fact that the implementation of criminal procedural compulsory measures is a procedural action that is based upon a particular specific circumstance that determines certain necessity in the course of the criminal procedure and is based upon the data obtained in the course of a particular procedure ${ }^{32}$.

As it follows from the analysis of juridical literature, opinions of legal professionals concerning the classification of criminal procedural compulsory measures - and the criteria thereof - tend to differ. The author of the thesis offers classifications of criminal procedural compulsory measure based upon such factors as the evaluation of the nature of legal coercion and its manifestation as well as the criminal case participant subject to the implementation of criminal procedural compulsory measures. It is also possible to classify criminal procedural compulsory measures basing on what authorized officials or institutions they are implemented by.

Acknowledging the fact that the regular criminal procedure is considered to be the fundamental form thereof, the implementation of the simplified form of criminal procedure suggests a considerable reduction of the duration of the procedure, which, in its turn, means the reduction of the time span within which criminal procedural compulsory measures are applied. It is

31 Божьев В.П. Уголовный процесс. Москва, 2008., стр. 47.

32 Berezins A. Apcietinājuma institūta teorētiskās un prakstiskās problēmas // Jurista Vārds, 2012, Nr. 13 (712), 21. lpp. 
worth emphasizing though that the implementation of a differentiated approach towards criminal proceedings does not indicate a lack of legitimacy, but, quite contrarily, it allows to achieve the main purpose of the criminal procedure rationally and effectively utilizing resources.

Every act of crime is not only the basis for a criminal investigation and punishing the guilty persons, but also a conflict that has to be resolved. Traditional criminal law does not openly deny this point, however, nor does it emphasize the importance of bringing the resolution to the aforementioned conflict and prescribes that the problems arising in connection with the conflict are resolved by the state, which often fails to satisfy the feelings of the participants of the procedure and does not prevent new criminal acts from happening. Criminal law turns a dispute that only involves a few persons into a full-scale public dispute. Quintessentially, the state thus demonstrates its proactive attitude and preparedness to take action in the field of protection of both human rights and those of the public. Although, by reserving the regulation of criminal procedural relations within its competence, the state demonstrates the willingness to be in total control of the process, independently resolving all the issues in connection with the crime ${ }^{33}$.

Thus, it may be concluded that there is a specific peculiarity inherent in the state - the monopolization of coercive power with its application allocated to state institutions including law enforcement authorities. State coercion is multiform. There exist the different types of it including criminal legal, criminal procedural, administrative and disciplinary coercion as well as other coercion types. Every type of coercion is characterized by a body of legal norms regulating the grounds and provisions for and the order of the implementation of every criminal procedural compulsory measure in particular.

33 Judins A. Atjaunojošā Justīcija nepilngadīgo noziedzības kontekstā: Baltijas valstis Eiropas dimensijā. Rīga: Providus, 2010. http://at.gov.lv/files/uploads/files/ docs/2011/atjaunojosa\%20justicija.pdf 
In connection with this, scientist N. Kapinus expresses an opinion that criminal procedural compulsory measures are nothing but statutory instruments of the state's legal pressure aiming to overcome negative circumstances as well as to achieve the main purpose of the criminal procedure ${ }^{34}$. Procedural coercion first and foremost applies to individuals having the right to defense. Nevertheless, the restriction of human rights and interests has to be feasible and adequate and, simultaneously, sufficient, in order to ensure particular procedural behavior. Criminal procedural compulsory measures are measures of ensuring the performance of procedural duties; they are only connected with the temporary restriction of the sphere of human rights and interests. No criminal procedural compulsory measure in itself is a penalty despite the fact that it is connected with restricting human rights and interests for legal reasons ${ }^{35}$.

Conflict management raises the need for determining the possible reasons of the conflict, analyzing the situation as well as for implementing specific compulsory measures for prevention and deterrence of the negative consequences that may potentially hinder the process of achieving the primary purpose of the criminal procedure.

\subsection{The system of criminal procedural compulsory measures in Latvia}

This chapter provides the analysis of compulsory measures not involving the deprivation of liberty, specifically, that of the legal regulation of detention and compulsory measures not involving deprivation of liberty and related issues based on the assessment of the scientific implications and legal

34 Капинус Н.И. Процессуальные гарантии прав личности при применении мер пресечения в уголовном процессе: Монография. Москва, 2007, стр.12

35 Meikališa $\bar{A}$. Kriminālprocesuālo piespiedu līdzekḷu piemērošanas mehānisms kriminālprocesā. //Zinātniski praktiskās konferences "Latvijas Kriminālprocesa likuma piemērošanas pirmā gada problēmas” materiāli. Rīga, LPA, 2006., 147. lpp. 
practice materials in this area. It is worth noting that the framework of the present doctoral thesis does not include any comparison of legal systems of other countries, recognizing the findings by world famous scientists stressing the importance of an in-depth analysis of the economic, political, ideological, religious, historical, demographic and geographical characteristics of the countries in such a case.

The procedural compulsory measure of conveyance by force (alongside with detention and placement under arrest) may imply the use of physical coercion. The actual CPL regulates the implementation of this compulsory measure by stating that conveyance by force may be applied in situations when it appears necessary to ensure the participation of a person who without a valid reason fails to appear on summons issued by the person directing the procedure. It is worth noting though, that CPL does not exactly specify what is to be understood by the valid reason. One could presume that valid reasons might comprise a set of external circumstances such as, for instance, illness, late receipt of the summons, failure in mass transit system operation, the effect of natural hazards and so forth. It is necessary to take into consideration the implication included in the decision of the Department of Criminal Cases of the Senate of the Supreme Court of the Republic of Latvia, case No SKK-193/2012 which suggests that if the victim fails to attend the court session without notifying the court of the reason of their absence and having been timely (and in compliance with the law) notified about the court session, it is considered that the person has failed to appear in court without a valid reason ${ }^{36}$. It is necessary to emphasize that the court is not obliged to look for additional evidence aimed at either justifying or not justifying the absence of the person if

36 Latvijas Republikas Augstākās tiesas Senāta Krimināllietu departamenta 2012. gada 22. marta lēmums lietā Nr. SKK-193/2012, Jurista Vārds, 2012, Nr.25(724), 30. lpp. 
the said person themselves has either failed to justify it or succeeded to submit valid evidence in accordance with the order specified in regulatory legal acts ${ }^{37}$.

There has been a long discussion concerning whether conveyance by force is essentially characterized by the deprivation of liberty ${ }^{38}$. The question whether conveyance by force curtails such fundamental constitutional rights as the right to liberty and the right to physical integrity also remains topical ${ }^{39}$. This view is illustrated by the implications and conclusions included in particular judgments of the ECHR. Forcing a person into the car and forced transportation of the person against their will was found in the case of Foka v. Turkey, where a person was forcibly conveyed to a police office, which, according to the ECHR, infringed the applicant's right to freedom of movement as laid out in Article 5 of the Convention for the Protection of Human Rights and Fundamental Freedoms (Convention) ${ }^{40}$. In its turn, in the case of De Wilde, Ooms and Versyp v. Belgium another infringement of the right to liberty was found by the ECHR as a person was allocated a duty to follow a law enforcement official to a particular place ${ }^{41}$.

CPL prescribes a wide range of 11 different security measures. This diversity of security measures agrees with the perspective of the ECHR, as it has frequently been emphasized in ECHR sessions that in the process of

37 Latvijas Republikas Ministru kabineta 17.08.2012. vēstule Nr. 18/TA-664. tap.mk.gov.lv/doc/2005/VMinfo_270712_Saeima.664.docx

38 Meikališa Ā., Strada-Rozenberga K. Pārmaiṇu laiks kriminālprocesā. V. Procesuālie piespiedu līdzekḷi un sankcijas. // Jurista Vārds, 2006, Nr.26(429) http://www. jurustavards.lv/?menu=DOC\&id=138965

39 Шевелева С. В. Уголовно-процессуальное принуждение, связанное с физическим воздействием, и гарантии его законности и обоснованности // Нижний Новгород, 2006, http://www.unn.ru/pages/disser/23.pdf

40 Eiropas Cilvēktiesību tiesas spriedums lietā: Foka v. Turkey, judgment of 24 June 2008, application no. 28940/95, para 78. http://hudoc.echr.coe.int/sites/eng/ pages/search.aspx?i=00187175\#\{"itemid":["001-87175"]\}

41 Eiropas Cilvēktiesību tiesas spriedums lietā: De Wilde, Ooms and Versyp ("Vagrancy") v. Belgium, judgment of 18 June 1971, application no. 2832/66; 2835/66; 2899/66. http://hudoc.echr.coe.int/sites/eng/pages/search.aspx ?i=00157606\#\{ "itemid":["001-57606"]\} 
making the decision concerning the compulsory measure to be applied, the opportunity of implementing the least intrusive measure possible must be considered $^{42}$. It seems reasonable to consider that the choice of one particular compulsory measure is conditioned by the nature and harmfulness of the criminal offence, the character of the suspect or accused, his or her family situation, health, and other conditions. The person directing the proceedings shall choose a procedural compulsory measure that infringes upon the basic rights of a person as little as possible, and is proportionate.

Compulsory measures are applied to achieve the goals laid out in CPL providing there is a valid reason. A security measure shall be applied as a procedural compulsory measure to a suspect or an accused if there are grounds for believing that the relevant person will continue criminal activities, or hinder pre-trial criminal proceedings or court or avoid such proceedings and court. In such a case this possibility is both the basis for the selection of a compulsory measure and the circumstance to be considered in the process of selecting the specific compulsory measure; and the legislator, pointing out the circumstances to be taken into consideration in the process of selecting the specific compulsory measure, has presumed the relevant degree of realization probability. The probability of new acts of crime has to be rather high and is supposed to be based on facts relating to the characterizing data on the

42 See, for example, Eiropas Cilvēktiesību tiesas spriedums lietā: Idalov v. Russia, judgement of 22 May 2012, application no. 5826/03. http://hudoc.echr.coe.int/ sites/eng/pages/search.aspx?i=001-110986\#\{"itemid":["001-110986"]\}; $\quad$ Eiropas Cilvēktiesību tiesas spriedums lietā: Khudoyorov v. Russia, judgement of 12 April 2006, application no. 6847/02. http://hudoc.echr.coe.int/sites/eng/pages/search. aspx?i=001-70865\#\{"itemid":["001-70865"]\}; Eiropas Cilvēktiesību tiesas spriedums lietā Lelièvre v. Belgium, judgement of 8 November 2007, application no. 11287/03. http://sim.law.uu.nl/sIm/CaseLaw/hof.nsf/2422ec00f1ace923c1256681 002b47f1/c6ece051f116f4ffc1257386003bd3d2?OpenDocument; Eiropas Cilvēktiesību tiesas spriedums lietā: Ambruszkiewicz v. Poland, judgement of 23 October 2006, application no. 38797/03.http://hudoc.echr.coe.int/sites/fra/pages/search. aspx\#\{ "languageisocode":["FRA"],"itemid":["001-75344"]\} 
personality and behavior of the accused/the suspect. It is not finding the facts justifying the application of criminal procedural compulsory measures that is the main duty of the person directing the procedure, but ensuring the progress of the criminal procedure by preventing or eliminating risks that might potentially hinder it $^{43}$.

Security measures may be applied to the suspect or the accused. The person is recognized as the suspect in the event of the body of evidence providing the grounds for assumption by the person directing the procedure that the criminal offence to be investigated is likely to have been committed by a certain person. In connection with this it is essential to keep in mind that in compliance with part 3 of Section 398 of CPL, a person may be recognized as a suspect, and a security measure may be applied to such person, only from the moment when the offence being investigated may be qualified on the basis of a concrete Section of the Criminal Law. This is an essential matter, as, in initiating criminal proceedings, the actions of the person being investigated may be qualified only on the basis of jurisdiction at the object of the group of criminal offences and, when sufficient evidence has been acquired, the offence regarding which an investigation has been commenced shall be qualified on the basis of a concrete Section of the Criminal Law.

The law prescribes that such security measures as report of the address for the receipt of consignment, reporting to the police authority at a specific time, prohibition from approaching a specific person or location, prohibition from a specific employment and prohibition from departing from the State may be implemented in addition to any other security measure. It is worth noting though, that all the aforementioned security measures may also be applied independently. Translated grammatically, the legal regulation of part 4 of Section 243 of CPL implies that the law does not prescribe the exact

43 Meikališa Ā. Drošības līdzekḷu kriminālprocesuālā reglamentācija Latvijas likumdošanā. Rīga, 1995, 44. lpp. 
combination in which the aforementioned security measures may be applied in addition to one of the main security measures. This means that in addition to the main security measure applied, several (or even all) of the aforementioned security measures may be implemented at the same time. It is possible to simultaneously apply those in addition to the security measures related to the deprivation of liberty. This opportunity provided by the law allows the person directing the proceedings to rather efficiently restrict the body of fundamental human rights and freedoms in the process of choosing the security measures to be applied. Supporting the possibility of implementing a combination of security measures provided by the legislator, it is necessary though to emphasize the importance of the assessment of the feasibility and practicality of combining the aforementioned measures in every particular case.

Report of the address for the receipt of consignment (CPL Section $252^{1}$ ) is the duty of a person to immediately, but not later than within one working day, to notify the person directing the criminal proceedings regarding the change of an address for receiving consignments indicating a new address. This compulsory measure was introduced on 1 July 2012 upon entry into force of the amendments to CPL adopted on 24 May $2012^{44}$. Analyzing the legal regulation of this security measure it is possible to make a point of the fact that its formulation does not specify precisely starting from which moment the suspect/the accused is placed under the duty to inform the person directing the proceedings regarding the change of the address. This raises difficulties for the person directing the proceedings in implementing this security measure and in specifying to the person when it will be necessary for them to notify the person directing the proceedings about the change of address in order to observe the requirements of the law. The amendment to the CPL section determining this security measure could be formulated as follows: "Report of the address for the

44 Grozījumi Kriminālprocesa likumā. Latvijas Republikas likums („LV”, 92 (4695), 13.06.2012.;) [stājas spēkā 01.07.2012.]. 
receipt of consignment is the duty of a person to immediately, but not later than within one working day from the change of an address, to notify the person directing the criminal proceedings regarding the change of an address for receiving consignments indicating a new address".

Reporting to the police authority at a specific time (Section $252^{2}$ of $\mathrm{CPL}$ ) is a duty imposed by a decision of a person directing the proceedings to a suspect or accused to report to the police authority according to his or her place of residence. Similarly to the security measure of the report of the address for the receipt of consignment, this security measure was introduced on 1 July 2012. It is worth noting that the introduction of this measure to CPL is rather supportable, however, it would be advisable to amend the legal norm regulating this security measure by adding an essential specification in determining the frequency of reporting to the police authority. Therefore, the possible suggestion for CPL Section $252^{2}$ might be worded as follows: "Reporting to the police authority at a specific time is a duty imposed by a decision of a person directing the proceedings to a suspect or accused to at a specific time (but not more frequently than 3 times in a week) report to the police authority according to his or her place of residence".

Prohibition from approaching a specific person or location (Section 253 of CPL) is a restriction upon a suspect or accused, provided for with a decision of a person directing the proceedings (CPL Section $253^{1}$ ): from being located closer than the distance referred to in a decision from the relevant person, from having physical or visual contact with such person, and using means of communication, or techniques for transferring information, in order to make contact with such person. Implementing this security measure requires a motivated decision precisely determining the restrictions imposed on the suspect/the accused. In its turn, a prohibition from approaching a specific location (CPL Section $253^{2}$ ) is a restriction, provided for with a decision of a person directing the proceedings, upon a suspect or accused from visiting the 
relevant location, or being located closer than the distance referred to in the decision. Concurring with the opinion of another author, it is possible to conclude that practically it is only possible to initiate the identification of noncompliance with the security measure upon receiving a report from a person stating that the suspect/the accused has broken the requirements of this security measure, in connection with which it would be necessary for the implementation of this security measure to notify the person who the suspect/the accused is prohibited from approaching ${ }^{45}$. Therefore, it would be feasible to suggest adding the second sentence to CPL Section $253^{1}$ : "The notification concerning the implementation of this restriction shall be given to the person that the suspect/the accused is prohibited from approaching in compliance with the judgement rendered".

Prohibition on Specific Employment (CPL Section 254) means a restriction upon a suspect or accused, specified with a decision of a person directing the proceedings, from performing a specific type of employment (activities) for a time, or from execution of the duties of a concrete position (job). The implementation of this security measure suggests the restriction of the right of a person to freely choose their employment and workplace according to their abilities and qualifications as laid out in Section 106 of the Satversme. In such a case problematic aspects might arise in the situation when a person is denied the opportunity of doing their everyday work and, alongside with that, the opportunity to receive payment, simultaneously having no legal opportunity to work in a different job and thus provide for their living ${ }^{46}$.

45 See, for example, Meikališa Ā. Kriminālprocesuālo piespiedu līdzekḷu piemērošanas mehānisms kriminālprocesā.// Zinātniski praktiskā konference „Latvijas Kriminālprocesa likuma piemērošanas pirmā gada problēmas”. Rīga, 2006, 152.lpp.; Judins A. Ar brīvības atņemšanu nesaistītie drošǐbas līdzekḷi. - Rīga: Providus, 2008.lpp. 76.

46 Meikališa Ā. Kriminālprocesuālo piespiedu līdzekḷu piemērošanas mehānisms kriminālprocesā. //Zinātniski praktiskā konference „Latvijas Kriminālprocesa likuma piemērošanas pirmā gada problēmas”, Rīga, 2006, 153.lpp. 
Prohibition on Departure from a State (CPL Section 255) is a restriction, specified by a decision of a person directing the proceedings, upon a suspect or accused to depart from a state without the permission of the person directing the proceedings. This compulsory measure restricts the right of a person to freely depart from Latvia laid out in Article 98 of the Satversme. Analyzing the essence of this security measure it is worth noting that a person this security measure is applied to has the right to freely move in the territory of Latvia, however, the permission of the person directing the proceedings is necessary to depart from the state. It is worth mentioning though that CPL does not prescribe the exact procedure of obtaining such permission or the form it comes in (written or spoken). Therefore, it would be feasible to suggest prescribing the obtainment of a written permission of the person directing the proceedings.

Residence in a specific place (Section 256 of CPL) is a written obligation of a suspect or accused to reside during the time indicated and at the place specified by a person directing the proceedings or to not leave the specifically indicated place of residence or temporary residence for longer than 24 hours without the permission of the person directing the proceedings, as well as to arrive without delay on the basis of a summons of the person directing the proceedings, or to fulfill other criminal-procedural duties.

Interpreting the legal formulation of this security measure it is possible to conclude that the difference between the previous version and the version that is currently in effect is that the latter is supplemented with the duty imposed on the suspect/the accused to reside during the time indicated at the place specified by a person directing the proceedings. The general character of the formulation can hinder the practical application of the aforementioned security measure. Also, controlling the fulfillment of the duty imposed cannot possibly be straightforwardly assessed, as, analyzing the meaning of the word 
"location" in Latvian thesaurus dictionary ${ }^{47}$, it is possible to find various definitions of the word. All of the above-mentioned factors create the conditions for overly liberal interpretation of CPL Section 256.

Making a suggestion within the framework of the present doctoral thesis concerning the legal regulation of the security measure laid out in Section 256 of CPL, it would be advisable to formulate the aforementioned section as follows: "Residence in a specific place is a written obligation of a suspect or accused to reside during the time indicated and at the place specified by a person directing the proceedings and indicated by the suspect or accused as the place of their permanent residence or temporary stay, or to not leave the specifically indicated place of residence or temporary residence for longer than 24 hours without the permission of the person directing the proceedings, as well as to arrive without delay on the basis of a summons of the person directing the proceedings, or to fulfill other criminal-procedural duties".

Bail (CPL Section 257) is a monetary sum, specified with a decision of a person directing the proceedings, that has been transferred to the depository (storage) of a credit institution specified by a person directing the proceedings in order to ensure the arrival of a suspect or accused on the basis of a summons of a person directing the proceedings, and the execution of other procedural duties specified in the Law.

CPL does not prescribe any restriction in connection with the scope of bail persons - bail can be pledged by any person regardless of the way the said person is related to the suspect/the accused. It is worth noting that there has been considerable discussion in juridical literature in connection with the establishment of the institution of the bail bondsman ${ }^{48}$, whose sphere of

\footnotetext{
47 Skaidrojošā vārdnīca. http://www.tezaurs.lv/sv/?w=vieta

48 Петухова Т. Залог как мера пресечения // IV Starptautiskās jauno pētnieku un studentu zinātniski praktiskās konferences "Izaicinājumu un iespēju laiks: problēmas, risinājumi, perspektīvas" rakstu krājums, Rīga: 2014, 84.-88.lpp.
} 
competence would comprise pledging money as bail for the appearance of suspects/the accused carried out on a fee-paying basis, which would allow to expand the scope of persons so that the security measure could not only be applied to well-off individuals. One must suppose that Latvia would also benefit from the idea of creating the institution of the professional bail bondsman that would facilitate and encourage a more frequent implementation of this security measure taking into consideration its humanistic nature. Then again, the professional bail bondsman will be motivated by the opportunity to charge a fee for their services. It is essential to emphasize that CPL prescribes specific time frames within which bail can be paid - one month from the moment of implementation of arrest in the event of applying this measure with the possibility of bail. Then again, in the event of implementing bail as an independent security measure, no specific time frames are set for paying it. In order to solve this problem, it is possible to suggest supplementing part 3 of Section 257 of CPL for it to read as follows: "A bail may be paid within the period of 10 days from the moment the decision on the implementation of this security measure is made or within the period of 10 days after the moment the decision is made by the investigating judge in situations when the appeal is made against the amount of bail".

According to the $\mathrm{ECHR}^{49}$, when making a decision to arrest the investigating judge must consider the possibility of application of security measures not related to the deprivation of liberty (including bail). An automatic bail refusal without court control is a violation of part 3 of Article 5 of the Convention $^{50}$. It is worth noting that the purpose of the guarantee laid out in

49 Eiropas Cilvēktiesību tiesas spriedums lietā: Vrenčev v. Serbia, judgement of 23 September 2008, application no. 2361/05. http://hudoc.echr.coe.int/sites/eng/pages/ search.aspx?i=001-88554\#\{"itemid":["001-88554"]\}

50 See, for example, Eiropas Cilvēktiesību tiesas spriedums lietā: Piruzyan v. Armenia, judgement of 26 June 2012, application no. 33376/07. http://sim.law. uu.nl/SIM/CaseLaw/hof.nsf/d0cd2c2c444d8d94c12567c2002de990/bd5e02e2a1b3d 
part 3 of Article 5 of the ECHR is not the repair of material damage following from the act of crime but ensuring the fulfillment of the duties of the suspect/the accused.

The author of the present thesis concludes that the application of the security measure of bail has effect upon the material interests of a person, thus effectively motivating the person to fulfill their duties in the course of criminal proceedings. Being an alternative to arrest, bail does not restrict personal freedom or inviolability of a person simultaneously reducing the costs and expenses of the state connected with keeping a person under arrest.

A personal guarantee (CPL Section 258) is a written obligation with which a natural person in accordance with the decision of a person directing the proceedings on application of a security measure guarantees that a suspect or accused will arrive on the basis of a summons of a person directing the proceedings, and will fulfill other procedural duties. The personal guarantor may be a physical person who has expressed such desire and regarding which a person directing the proceedings is in confidence that he or she can ensure the fulfillment of obligations. There shall be not less than two personal guarantors. In accepting a bail, a person directing the proceedings shall inform the guarantors regarding the essence of the concrete criminal proceedings in connection with which a security measure has been applied, and shall explain the consequences that will come about if the provisions of such security measure are not complied with. If the provisions of a security measure are violated, a fine shall be applied on a guarantor, with a decision of an investigating judge or a court decision, in the amount of 10 to 30 of the minimal monthly wage specified in the Republic of Latvia.

224c1257a22003f916e?OpenDocument; Eiropas Cilvēktiesību tiesas spriedums lietā: S.B.C. v. the United Kingdom, judgement of 19 June 2001, application no. 39360/98. 
It is worth mentioning that CPL does not provide personal guarantors with the opportunity to withdraw from the obligations assumed. In contrast, this opportunity is granted to a unit commander (supervisor) under whose supervision a soldier is placed and who may withdraw from the supervision of the soldier at any time. It is possible to conclude that the unavailability of such an opportunity to a personal guarantor is not reasonable. Therefore, it is possible to suggest amending part 2 of Section 258 of CPL and formulating it in the following manner: "The personal guarantor may be a physical person who has expressed such desire and regarding which a person directing the proceedings is in confidence that he or she can ensure the fulfillment of obligations. There shall be not less than two personal guarantors. The personal guarantor may withdraw from personal guarantor duties at any time”. Moreover, it is worth noting that the legal consequences part 4 of Section 258 of CPL provides for noncompliance with the requirements of this security measure - a fine up to the amount of 10 of the minimal monthly wage specified in the Republic of Latvia - can be evaluated as disproportionate and those that are more likely to discourage the prospective personal guarantor from assuming the responsibilities rather than to motivate the guarantor to assume those. It is worth adding that noncompliance with the requirements of other security measures, such as placement of a soldier under the supervision of a unit commander (supervisor) or placement of a minor under the supervision of parents or guardians results in legal consequences, specifically, the possibility of the court applying a fine up to the amount of 10 of the minimal monthly wage specified in the Republic of Latvia to be paid by the unit commander (supervisor) under whose supervision the soldier is placed or by the person under whose supervision the minor is placed. In order to harmonize the issues in connection with the regulation of legal consequences, it would be advisable to formulate part 4 of Section 258 of CPL as follows: "If the provisions of the security measure are violated, a fine shall be applied on the guarantor, with a 
decision of an investigating judge or a court decision, in the amount of up to 10 of the minimal monthly wage specified in the Republic of Latvia”.

The placement of a soldier under the supervision of a unit commander (supervisor) (CPL Section 259) is a written obligation of the unit commander (supervisor), in accordance with a decision of a person directing the proceedings, regarding the application of a security measure to ensure that a suspected or accused soldier will arrive on the basis of a summons of a person directing the proceedings, and fulfill other procedural duties. The placement of a soldier under the supervision of a unit commander (supervisor) shall be applied only with the consent of the unit commander (supervisor). The status of a soldier is the legal status of a person performing active military service; the status is terminated once when active military service has been completed. It remains ambiguous whether the commander (supervisor) can ensure the fulfillment of duties by the suspect/accused soldier when the said soldier is on leave. In such a situation it would be feasible to change the security measure applied to the soldier as in the placement of a soldier under the supervision of a unit commander (supervisor).

\section{The placement of a minor under the supervision of parents or} guardians (CPL Section 261) is a written obligation of one person or several of such persons, in accordance with a decision of a person directing the proceedings, regarding the application of a security measure to ensure that the suspected or accused minor will arrive on the basis of a summons of a person directing the proceedings, and fulfill other procedural duties. Placement under the supervision of parents or guardians shall be applied only with the consent of such persons and the minor him or herself. Similarly to part 4 of Section 258 of CPL and part 4 of Section 259 of CPL, part 5 of Section 260 of CPL provides legal consequences for noncompliance with the requirements of this security measure, specifically, if a suspect or accused, who is a minor does not fulfill his or her procedural duties, an investigating judge or a court may apply a fine of 
up to the amount of 10 of the minimal monthly wage specified in the Republic of Latvia. Analyzing the peculiarities of the legal regulation of Section 258, 259 and 260 of CPL, it is worth noting that procedural sanctions - imposing a fine for noncompliance with the requirements of the security measures of the placement of a soldier under the supervision of a unit commander (supervisor) and the placement of a minor under the supervision of parents or guardians are the procedural option at the disposal of the investigating judge or the court, not their obligation, as it is provided in Section 258 of CPL for noncompliance with the requirements of the security measure of personal guarantee ${ }^{51}$. Moreover, as it has already been stated above, it may be suggested to harmonize this approach by introducing alterations to part 4 of Section 258 of CPL.

Placement under police supervision (CPL Section 261) is, essentially, the relocation and the restriction of the discretionary power of a suspect or accused, specifically, with the provision that the relevant person shall not change his or her permanent or temporary place of residence without the permission of a person directing the proceedings, visit the locations or institutions referred to in the decision, meet with the persons referred to in the decision. Moreover, such person shall be located in his or her place of residence during specific hours of the day, and that he or she shall declare him or herself

51 See, for example, part 4 of Section 258 of CPL: If the provisions of a security measure are violated, a fine shall be imposed on a guarantor, with a decision of an investigating judge or a court decision, in the amount of 10 to 30 of the minimal monthly wage specified in the Republic of Latvia; part 4 of Section 259 of CPL: If a suspect or accused does not fulfil his or her obligations, the unit commander (supervisor) under the supervision of whom he or she is located, an investigating judge, or the court may impose a fine up to the amount of 10 of the minimal monthly wage specified in the Republic of Latvia.; part 5 of Section 260 of CPL: If a suspect or accused, who is a minor does not fulfil his or her procedural duties, an investigating judge or a court may impose a fine of up to the amount of 10 of the minimal monthly wage specified in the Republic of Latvia upon the persons under whose supervision the minor is located. 
not more than 3 times per week at the police institution according to the place of residence thereof. Restrictions shall be determined taking into account the work or study conditions of a suspect or accused.

In order to examine the conformity of a person with the restrictions on freedom of movement and discretionary power, police employees have the right to visit the person at the place of residence indicated in the decision at the front door of the place of residence. The person has the duty to open the front door of the place of residence during examination and to be at the front door within the view of the police employee until the end of examination.

Prof. K. Strada-Rozenberga concludes ${ }^{52}$ that there is an uncomfortable aspect to the differentiated approach of the legislator towards the selection of terms used in connection with the place the person is obliged to report the change of, not change, remain at, etc. For instance, in the aforementioned Section $252^{1}$ of CPL the place is defined as "the place of residence", in Section 256 of the new version of CPL the definition reads "the place of residence or temporary residence", but Section 261 reads "permanent or temporary place of residence". One would dare to doubt that the legislator might have purposefully permitted this sort of difference between the concepts presuming that every aforementioned concept has its own individual meaning under certain circumstances. Then again, she made a rather feasible suggestion in connection with the introduction of a uniform definition that, according the author of this thesis, might read as "place of residence". In addition to all the aforementioned, the author of this paper would like to emphasize that the definition of the term "place of residence" as provided by the legislator in the Law on Declaration of Place of Residence, reads as follows: “A place of residence is any place (with an address) connected with immovable property freely selected by a person, in

52 Strada-Rozenberga K. Tiesu darbam aktuālākais 2012. gada 24. maija kriminālprocesa likuma grozījumos // Augstākās tiesas biḷ̂etens, 2013, 6: 73.-81.lpp. http://at.gov.lv/files/uploads/files/docs/2013/ATBiletens6_web.pdf 
which the person has voluntarily settled with an intention to reside there expressed directly or implicitly, in which he or she has a lawful basis to reside and which has been recognized by him or her as a place where he or she is reachable in terms of legal relations with the State or local government",53.

It is worth noting that the current regulation of security measure provisions is in compliance with the provisions of Recommendation No. R(92)16 on the European Rules on Community Sanctions and Measures adopted by Committee of Ministers of the Council of Europe ${ }^{54}$. The aforementioned Recommendation emphasizes the fact that no measure shall be implemented for an unlimited period of time, and the duration of the period of its application is determined by the authorized institution in compliance with the law. Moreover, the length of the period of application of the security measure must be proportionate to the seriousness of the offence the person is suspected for/accused of. Besides, in selecting the security measure to be applied, the personal situation of the suspect/accused must be considered.

Discussing the prospects of development of the system of compulsory measures not related to deprivation of liberty, it is important to emphasize the practicality of a new security measure - electronic surveillance. It is worth noting that an electronic surveillance device may be also used in the control of compliance with the restrictions under the requirements of other security measures such as, for instance, prohibition from approaching a specific person or location, prohibition on departure from a state, residence in a specific place, placement under police supervision and house arrest. Presumably, electronic surveillance may possibly affect the behavior of a person keeping them from

53 Dzīvesvietas deklarēšanas likums. Latvijas Republikas likums ("LV", 104 (2679), 08.07.2002.; Ziṇotājs, 16, 22.08.2002.) [stājas spēkā 01.07.2003.] ar grozījumiem.

54 Recommendation No.R(92)16 of the Committee of Ministers to member states on the European rules on community sanctions and measures// http://pjpeu.coe.int/documents/3983922/6970334/CMRec+(92)+16+on+the+European+rules +on+community+sanctions+and+measures.pdf/01647732-1cf7-4ea8-88ba$2 \mathrm{c} 041 \mathrm{bc} 3 \mathrm{f} 5 \mathrm{~d} 6$ 
failing to comply with the duties imposed within the framework of a particular security measure. Therefore, the introduction of electronic surveillance might help optimize the process of controlling the security measure of placement under police supervision eliminating the necessity for police officers to pay regular visits to the suspect/the accused at their place of residence. Undoubtedly, the introduction of electronic surveillance as an independent security measure provided by CPL would be rather feasible and would mean that contemporary technology is implemented to ensure the success of the criminal procedure and to facilitate the application of alternative security measures related to the deprivation of liberty.

Without downgrading the significance of security measures related to the deprivation of liberty and without denying the necessity of their application, it is still essential to thoroughly consider the possibility of applying a less intrusive security measure. The protection of human rights that is enshrined in Section 5 of the Convention determines its fundamental importance for a democratic society ${ }^{55}$. Any illegal deprivation of liberty means utter denial of the guarantees, which, in its turn, is a major violation of Section 5 of the Convention ${ }^{56}$. Personal liberty is a fundamental right enjoyed by everyone. The deprivation of liberty may have negative effect upon other fundamental rights,

55 Convention for the Protection of Human Rights and Fundamental Freedoms as amended by Protocols No.11 and No.14. http://conventions.coe.int/treaty/en/ treaties/html/005.htm

56 See, for example, Eiropas Cilvēktiesību tiesas spriedumus lietā: Cicek v. Turkey, judgment of 27 february 2001, application no. 25704/94, para 164, http://echr.ketse.com/doc/25704.94-en-20010227/; Eiropas Cilvēktiesību tiesas spriedumus lietā: Luluev and Others v Russia, judgment of 9 November 2006, application no. 69480/01, para §122. 350, http://www.srji.org/resources/search/52/

56 Roagna I. Protecting the right to respect for provate and family life under the European Convention on Human Rights. Council of Europe, Strasbourg, 2012, http://www.coe.int/t/dghl/cooperation/capacitybuilding/Source/documentation/hb11 _privatelife_en.pdf 
for instance, that of family and private life ${ }^{57}$, the freedom of expression ${ }^{58}$, the freedom of movement, etc. Moreover, the restriction of any freedom makes a person vulnerable, increasing the risk of being made subject to torture and inhuman or degrading treatment. The analysis of the legal regulation of the security measures related to the deprivation of liberty is called the analysis of criminal procedural detention.

It is worth noting that the right to habeas corpus or amparo procedures that have frequently been analyzed in ECHR cases ${ }^{59}$ mean that every person who has been subject to the deprivation of liberty by detention or arrest, has the right to instantly appear before the court that will make a decision concerning the legitimacy of the deprivation of liberty and its compliance with the procedure enshrined in the law, which is necessary in order to detect possible

57 Roagna I. Protecting the right to respect for provate and family life under the European Convention on Human Rights. Council of Europe, Strasbourg, 2012, http://www.coe.int/t/dghl/cooperation/capacitybuilding/Source/documentation/hb11 _privatelife_en.pdf

58 Murdoch J. Protecting the right to freedom of thought, conscience and religion under the European Convention on Human Rights. Council of Europe, Strasbourg, 2012, http://www.coe.int/t/dghl/cooperation/capacitybuilding/Source/documentation/hb09 _rightfreedom_en.pdf

59 Eiropas Cilvēktiesību tiesas spriedums lietā: the Lamy v. Belgium, judgment of 30 March 1989, Series A no. 151, § 27, application no. 10444/83, www.Echr.coe.int/Documents/Stats_violation_1959_2012_ENG.pdf; Eiropas Cilvēktiesību tiesas spriedums lietā: Lavents v. Latvia, judgement of 28 November 2002, application no. 58442/00, http://sim.law.uu.nl/sim/caselaw/Hof.nsf/ 1d4d0dd240bfee7ec12568490035df05/e39a38852cec221d41256c800045eb6e?Open Document; Eiropas Cilvēktiesību tiesas spriedums lietā: Brogan and others v. the United Kingdom, judgement of 29 November 1988, application no. 11209/84; 11234/84; 11266/84; 11386/85, http://hudoc.echr.coe.int/sites/eng/pages/search. aspx?i=001-57450\#\{"itemid":["001-57450"]\};European Court of Human Rights Finds Violations of the European Human Rights Convention in German Pre-trial Detention Procedures. German Law Journal. http://www.germanlawjournal. com/article.php?id=56; Acker J.R., Brody D.C. Criminal procedure. $-2013.3^{\text {rd }}$ ed., - 1-672 p. http://www.amazon.com/Criminal-Procedure-A-ContemporaryPerspective/dp/1449652344\#reader_1449652344 
indications of abusive treatment as well as to minimize any chance of illegal restriction of human freedom ${ }^{60}$.

Talking about procedural irregularities that are committed in the course of apprehension and their effect upon evidence and its admissibility, it is worth noting that the irregularities are to be considered, however, they do not affect the admissibility of evidence. Then again, the irregularities committed during apprehension in the course of investigative action such as search, interrogation, submission for identification and face-to-face confrontation, etc., quite contrarily, do affect the admissibility of evidence and may provide grounds for questioning the evidence.

Not underestimating the importance of compulsory measures related to the deprivation of liberty as part of the coercive mechanism of the state, it is worth emphasizing that the economic aspect of this issue must not be neglected, as the implementation of compulsory measures related to the deprivation of liberty poses considerable costs to be covered from the state budget. The greater the number of detained individuals and the number of those kept under arrest, the heavier is the financial burden the state has to carry. The costs may be reduced, though, by thoroughly considered, well-grounded, customized application of compulsory measures related to the deprivation of liberty.

It is worth noting that according to the perspective of the ECHR, the arrest order must be based on concrete grounds and a specific time-limit ${ }^{61}$ must be set. Making the decision concerning further implementation of arrest, the court must clarify the reason why this specific decision has been made. Even providing that there is initially a reason for arrest of a person, it is worth taking

60 Eiropas Cilvēktiesību tiesas spriedums lietā: McKay v. the United Kingdom, judgement of 3 October 2006, application no. 543/03, http://hudoc.echr. coe.int/sites/eng/pages/search.aspx?i=001-77177

61 Eiropas Cilvēktiesību tiesas spriedums lietā: Meloni v. Switzerland, judgement of 10 July 2008, application no. 61697/00. http://hudoc.echr.coe.int/sites/fra/pages/ search.aspx\#\{"itemid":["001-85776"]\} 
into consideration that the said reason might become insufficient over time ${ }^{62}$. ECHR also emphasizes the fact that within the period from 1998 to 2000 irrelevant use of the compulsory measure of arrest appeared to be a recurring problem. According to M. Mits (member of the President's Commission on Constitutional Law), the systematic irregularity revealed in connection with the implementation of arrest indicates recurrent, lasting and serious violation of the fundamental human right of freedom and security ${ }^{63}$. Moreover, Dr. sc. soc. A. Nevera points out that in the process of solving the problem of the feasibility of further implementation of arrest it will be necessary to use the criteria developed within the framework of ECHR judicature ${ }^{64}$, particularly, thorough assessment of the justifying facts ${ }^{65}$, their validity and sufficiency. Despite the fact that the severity of punishment is an essential component in evaluating the risks following from failure to appear in court or repetition of a crime, the seriousness of the charge cannot provide grounds for lasting pretrial arrest ${ }^{66}$.

62 Eiropas Cilvēktiesību tiesas spriedums lietā: Estrikh v. Latvia, judgement of 18 January 2007, application no. 73819/01. http://sim.law.uu.nl/SIM/CaseLaw/ hof.nsf/233813e697620022c1256864005232b7/0ca9c88419c27167c125726c00345d 00 ? OpenDocument

63 Mits M. Eiropas Savienības prasības cilvēktiesību jomā - strap mājas darbiem un brīvlaiku Latvijā. Eiropas Savienība un tiesiska valsts: Latvijas pieredze, Rīgas Juridiskā augstskola. - Rīga, 2009, 70.-85.lpp.

64 Eiropas Cilvēktiesību tiesas spriedums lietā: Pélissier and Sassi v. France, judgement of 25 March 1999, application no. 25444/94,http://hudoc.echr.coe. int/sites/eng/pages/search.aspx?i=001-58226\#\{ "itemid":["001-58226"]\}

65 See, for example, Nevera A. Impositon and extension of detention: standards of the European Court of Human Rights and Lithuania's practice. // Administratīvā un Kriminālā Justīcija, 2013, Nr.3(64), 48.-58. lpp.; Sluiter G. International Criminal Procedure. Rules and Principles // G. Sluiter, H. Friman, S. Linton, S. Zappala, S. Vasiliev (Eds.). - 2013, - Oxford University Press, Oxford, 1-1681.

66 See, for example, Eiropas Cilvēktiesību tiesas spriedums lietā: Piechowicz v. Poland, judgement of 17 April 2012, application no. 20071/07, http://www.tiesibsargs.lv/files/content/spriedumi/Pjehovics\%20pret\%20Poliju\%20\% 28Piechowicz\%20v.\%20Poland\%29.pdf; Eiropas Cilvēktiesību tiesas spriedums lietā: Michta v. Poland, judgement of 4 May 2006, application no. 13425/02, http://sim.law.uu.nl/sim/caselaw/Hof.nsf/1d4d0dd240bfee7ec12568490035df05/56c 9c49b5a9f466ec125716100418250?OpenDocument 
The terms of arrest laid out in CPL are an essential procedural guarantee of observation of fundamental human rights. The implementation of unnecessarily long arrest, that turns a security measure into a measure of torture, is not permissible.

In ECHR judgements the equality of arms principle has been frequently emphasized. The principle is connected with the right to a fair trial and suggests that a person who has the right to a defense also has the right to access the information necessary to verify the legality of this person's arrest ${ }^{67}$. This principle is a tool of ensuring proportionality and adequacy that harmonizes state coercion with the procedural safeguards of a person having the right to a defense. In recent years national courts have considerably improved their awareness of the Convention standards, the issues related to the implementation and prolongation of detention with formal approach being substituted for a motivated assessment taking into considerations the specific circumstances of every case. Moreover, on the national level there theoretically and practically exists an efficient measure of human rights protection aimed at tackling the complaints connected with excessively lengthy criminal proceedings ${ }^{68}$.

House arrest used as an alternative to arrest is of paramount importance to the system of criminal procedural compulsory measures, which,

67 See, for example, Eiropas Cilvēktiesību tiesas spriedums lietā: Garcia Alva v. Germany, judgement of 13 February 2001, application no. 23541/94. http://hudoc.echr.coe.int/sites/eng/pages/search.aspx?i=001-59208\#\{"itemid":["00159208"]\}; Eiropas Cilvēktiesību tiesas spriedums lietā: the Lamy v. Belgium, judgment of 30 March 1989, Series A no. 151, § 27, application no. 10444/83. www.Echr.coe.int/Documents/Stats_violation_1959_2012_ENG.pdf; Eiropas Cilvēktiesību tiesas spriedums lietā: Nikolova v. Bulgaria, judgement of 25 March 1999, application no. 31195/96. http://hudoc.echr.coe.int/sites/eng/pages/ search.aspx?i=001-58228\#\{"itemid":["001-58228"]\}; Gabrāns M. Aizturētas personas tiesību zināt aizturēšanas iemeslu analīze // Transformācijas process tiesībās, reǵionālajā ekonomikā un ekonomiskajā politikāa ekonomiski-politisko un tiesisko attiecību aktuālās problēmas. II Starptautiskās zinātniski praktiskās konferences rakstu krājums. - Rīga, - 2014, 55.-60.lpp.

68 Latvijas pārstāvja starptautiskajās cilvēktiesību institūcijās darba pārskats par 2013.gadu // http://www.mfa.gov.lv/parskats_2013.pdf 
undoubtedly, indicates the humanization of penal law policy. According to ECHR, the decision about the deprivation of liberty to be applied to a person has to be made taking into consideration a body of criteria comprising the type of offence, the duration, consequences and the conditions of punishment execution. Deprivation of liberty and restriction of liberty only differ in terms of their degree of intensity, but do not essentially differ in nature ${ }^{69}$. For instance, in connection with the case Lavents v. Latvia ${ }^{70}$ the ECHR stated that the applicant, who was placed under house arrest, remained alone in his apartment for the period of over 11 months under police supervision and the extent of restriction of his liberty was comparable to liberty deprivation as enshrined in Section 5 of the Convention ${ }^{71}$. Therefore, the author of the thesis suggests that it is only possible to appeal the restrictions imposed within the framework of a decision about the implementation of security measures related to the deprivation of liberty (as in arrest and house arrest) but not the very implementation of the measure itself ${ }^{72}$.

Numerous law enforcement authority systems are currently operating in the EU with every member state having a system of its own. The goal of the criminal procedural policy of the EU is the establishment of a common legal regulation system to combat terrorism and crime in order to guarantee a high level of security to its citizens as well as to strengthen international cooperation in the field. EU member state cooperation in the sphere of anticriminal effort

69 Eiropas Cilvēktiesību tiesas spriedums lietā: Amuur v. France, judgement of 25 June 1996, application no. 19776/92, http://hudoc.echr.coe.int/sites/eng/pages/search. aspx\#\{"appno":["19776/92"]\}

70 Eiropas Cilvēktiesību tiesas spriedums lietā: Lavents v. Latvia, judgement of 28 November 2002, application no. 58442/00. http://sim.law.uu.nl/sim/caselaw/ Hof.nsf/1d4d0dd240bfee7ec12568490035df05/e39a38852cec221d41256c800045eb 6e?OpenDocument

71 Eiropas Cilvēktiesību tiesas spriedums lietā: Mancini v. Italy, judgement of 2 August 2001, application no. 44955/98. http://hudoc.echr.coe.int/sites/eng/ pages/search.aspx?i=001-59626\#\{"itemid":["001-59626"]\}

72 Kazaka S., Groma J. Piespiedu līdzekḷu ietekme uz konflikta risināšanu kriminālprocesā. Administratīvā un Kriminālā Justīcija, 2012; 2 (59): 28.lpp. 
includes introducing practical improvements to the cooperation mechanism and harmonizing the work of the court and legal act systems ${ }^{73}$. It is essential that the member states (including Latvia) continue to strengthen their cooperation and share the best practices to carry out reforms aimed at enhancing the efficiency of their collaboration.

European Arrest Warrant (hereinafter referred to as EAW) is a judicial decision issued by one member state that another member state is obliged to comply with basing on the principle of mutual recognition. In Latvia the EAW procedure has been integrated into CPL as a surrender procedure with its specific order. In contrast with traditional surrender procedures EAW is characterized by innovative peculiarities. Observing and respecting fundamental human rights is an indispensable element of the EAW procedure.

CPL enshrines a differentiated approach to the legal regulation of criminal procedural measures implemented in the society laying out a different procedure for EU member states and other countries. The criminal procedural compulsory measures related to the deprivation of liberty implemented in the international cooperation in the field of criminal law as laid out in Part C of CPL are not systematized. Therefore it may be suggested to supplement Section 681 of $\mathrm{C}$ as follows: Criminal procedural compulsory measures related to the deprivation of liberty applied in the international cooperation in criminal matters. In the course of cooperation in criminal legal matters the rights of a person may be restricted by implementing the following compulsory measures:

1) Detention of a person subject to extradition to one of the EU member states;

2) detention of an individual for the purpose of further extradition; 3 ) arrest of a person subject to extradition to one of the EU member states; 4) temporary arrest; 5) extradition arrest; 6) temporary arrest prior to the receipt of a removal order; 7) temporary arrest after the receipt of a removal order; 8) detention with

73 Bogdan M. Comparative Law. Kluwer Law and Taxation Publishers. $-1^{\text {st }}$ edition, 1994, p.30-32. 
a view to temporary arrest; 9) takeover of a person convicted in a foreign state; 10) temporary arrest of a person convicted in a foreign state; 11) detention of a person convicted in an EU member state; 12) 11) temporary arrest of a person convicted in an EU member state.

Considerable amendments to CPL came into force on 1 July 2012 with the integration of Council Framework Decision 2009/946/TI, in which numerous irregularities identified in Chapter 16-17 of CPL were eliminated, particularly, the disunity of regulation of different kinds of punishment as laid out in Chapter 17, the ambiguity of the extent to which the regulation is applicable to foreign countries and EU member states, the ambiguity of the function of the Ministry of Justice as a cognizant institution in receiving and considering an order from another state and assessing the possible reasons for its rejection, by means of which the need for greater comprehensibility in CPL regulation was satisfied and the clarity of the text increased.

Facilitating international cooperation is one of the principles of further development of EU member states. It is essential for countries cooperating in their anti-criminal effort to achieve a sensible balance between efficiency and reliable guarantees ensuring that the fundamental rights of detainees and the provisions of the Convention are observed. This cooperation in every particular case must incorporate thorough assessment taking into consideration the magnitude of the offence, the event and the measures to be applied in the state of execution, particularly the fact that the event requires for the individual to be made subject to the deprivation of liberty. Measures related to the deprivation of liberty must be used in order to facilitate criminal prosecution for serious offences that cause considerable damage and by all means justify the application of these measures as well as to execute a sentence. The background of experience of international cooperation in the sphere of crime prevention accumulated in the EU can be characterized as advanced and unique. 


\section{THE GUARANTEES OF THE OBSERVATION OF THE RIGHTS AND FREEDOMS OF A PERSON IN THE IMPLEMENTATION OF CRIMINAL PROCEDURAL COMPULSORY MEASURES}

\subsection{The guarantees of a person in the implementation of criminal procedural compulsory measures}

International human rights documents - the Charter of Fundamental Rights of the EU and the Convention lay out the procedural safeguards for persons having the right to defense in a criminal procedure - the right to defense, the right to spoken interpretation and written translation in criminal proceedings, the right to be informed about the nature and cause of accusation, the right to seek review of the detention and the right to fair trial. Everyone who has been charged with an offence has the following fundamental set of rights: the right to be instantly informed in clear and unambiguous language about the nature and cause of the offence they are being charged with; the right to adequate time and facilities to prepare a defense; the right to self-defense, the right to use the assistance of counsel as well as the right to obtain legal help for free if the defendant cannot afford to cover legal expenses and if this is necessary for legal reasons; the right of counter interrogation of prosecution witnesses and the right to call defense witnesses to be interrogated in the same manner as the witnesses of prosecution; the right to free access to interpretation and translation if the defendant does not understand or speak the language of the court; the right to defense.

In 2009 EU Council meeting the ministers agreed ${ }^{74}$ on the general approach in relation to strengthening the rights of the suspects/accused persons

74 Eiropas Savienības Padomes 2969. Sanāksmes paziṇojums presei 14936/09 (Presse 306), 23.10.2009. // http://www.google.lv/url?sa=t\&rct=j\&q=\&esrc=s\&source =web \& 
in criminal proceedings by promoting mutual trust among member states. Thus, as a result of this, Resolution of the Council of 30 November 2009 on a Roadmap for strengthening procedural rights of suspected or accused persons in criminal proceedings ${ }^{75}$ was adopted with a view to ensure taking progressive measures in relation to the right to spoken interpretation and written translation, the right of getting access to information about the accusation and the rights, the right to legal advice and legal aid; the right to communication with relatives, employers and consular authorities, as well as special safeguards for suspected and accused persons who are vulnerable. The first measure adopted in compliance with the Roadmap was the adoption of Directive 2010/64/EU of the European Parliament and of the Council on the right to interpretation and translation in criminal proceedings ${ }^{76}$ in 2010 . It enshrines the general minimum standards that must be applied in relation to the information made available to suspected or accused persons concerning their rights and the offences they are charged with for the purpose of fostering mutual trust among the member states. The relevant law enforcement authority must, either in writing or in spoken form, inform the accused person promptly of his or her rights that are fundamental in order to guarantee fair trial. A letter of rights must be promptly issued to any person that has been made subject to the deprivation of liberty in connection with criminal proceedings. The letter

$\mathrm{cd}=8 \&$ ved=0CGQQFjAH\&url=http $\% 3 \mathrm{~A} \% 2 \mathrm{~F} \% 2$ Feuropa.eu $\% 2$ Frapid $\% 2$ Fpressrelease_PRES-09-

306_lv.doc\&ei=VooIVOH3O4b8ygORg4GACw\&usg=AFQjCNHdqF_dil9sCGbDqIImaVxuwsiTQ\&sig2=35aR_58qaujFPAL1ZOW9zg\&bvm=bv.74649129,d.bGQ

75 Padomes Rezolūcija 2009/C 295/01 par cel̦vedi aizdomās turētu vai apsūdzētu personu procesuālo tiesību stiprināšanai kriminālprocesā. 30.11.2009. ES Oficiālais Vēstnesis C 295. 04.12.2009. http://eur-lex.europa.eu/legal-content/LV/TXT/; ELX_SESSIONID=y1hTTkcWDfvzP4MnK6dGGcr8N1nTNYv70khC7p5JmBylB8 Z2Lnqs!760646899?uri=OJ

76 Eiropas Parlamenta un Padomes Direktīva 2010/64/ES (2010. gada 20. oktobris) par tiesībām uz mutisko un rakstisko tulkojumu kriminālprocesā. ES Oficiālais Vēstnesis L 280. 26.10.2010. http://eur-lex.europa.eu/legal-content/LV/TXT/ ?uri=OJ:L:2010:280:TOC 
must contain essential information on the possibility to appeal the legitimacy of detention, review the decision on detention or ask for temporary release as long as the aforementioned rights are granted by the legislation of the state. The accused person must have access to all the necessary information in connection with the charges he or she is facing in order to prepare his or her own defense and enjoy his or her guaranteed right to fair trial. The suspected or accused person must be promptly provided with detailed information concerning the possible legal qualification of the offence in order to ensure fair trial as well as to exercise the right to defense. The Directive enshrines the right of free access to the materials of the case. It is worth noting that the information on the procedural rights implemented must be made available in easily understandable form, and this written notice must be given to any person who has been made subject to the deprivation of liberty.

The principles of a state governed by the rule of law are essentially based on the balance between the core values and legal practice existing in the society $^{77}$. The principles also require that the result of criminal proceedings is fair in order for no person to be charged with an offence they did not commit and for the person who did commit an offence to be adequately punished. Resolving the issue of restricting the rights of an individual, it is necessary to decide whether the good of the community outweighs the importance of the protection of human rights and interests.

The efficiency of the functioning of criminal policy is not only assessed from the perspective of its compliance with legal norms, the management of law enforcement institutions, theoretical and practical achievements. Another essential factor to be taken into consideration that arises from national legal

77 Latvijas Republikas Satversmes tiesas 2000. gada 24. marta spriedums lietā Nr.0407(99) // www.satv.tiesa.gov.lv/upload/04-07(99).rtf 
acts and legally binding international agreements is compliance with and respect to the universal human norms and values ${ }^{78}$.

Contemporary criminal law is not a body of technical instructions, but rather a domain of law that is based upon universal human rights norms. Legal norms regulating the implementation of security measures practically reflect the compromise between the interests of a criminal procedure and those of human rights. Prescribing the restriction of human rights, these norms precisely determine the maximum legally permissible extent of suppression, set out the procedure of implementation as well as provide the possibility of an appeal. The restriction of human rights in criminal proceedings is permissible as long as it is necessary for the purpose of ensuring speedy and progressive case investigation and trial. The intensity of this restriction within the framework of criminal proceedings, however, should be minimized to the extent possible. Making a decision on the implementation of a security measure, the person directing the proceedings must balance out the interests of the criminal procedure and fundamental human rights guaranteed by the Satversme and other legal acts. Protecting the interests of the criminal procedure does not permit unjustified or unproportional restriction of human rights ${ }^{79}$.

Criminal procedural trends connected with human rights observation and the protection of factual rights and interests of convicted persons emerged when CPL came into force. The vision of CPL suggests that the court ensures the control of measures restricting human rights in the course of pre-trial investigation, therefore the position of the investigating judge was established in courts, simultaneously aiming to meet the requirement of international law

\footnotetext{
78 Zahars V. Kriminālpolitika: mūsdienu tendences un procesi. - Daugavpils Universitātes Akadēmiskais apgāds „Saule”, 2014, 7.lpp.

79 Judins A. Ar brīvības atņemšanu nesaistītie drošības līdzekḷi. Rīga, 2008, lpp. 10.
} 
for fair and impartial trial ${ }^{80}$. The requirement to ensure an impartial trial is connected with numerous factors also including the necessity of the segregation of duties, as judges in court must not be involved in the process of pre-trial investigation of a criminal offence, however, the aforementioned pre-trial investigation process in its turn requires for the court to control the restriction of human rights ${ }^{81}$. The institute of the investigating judge came into existence upon coming into effect of CPL. The institute of the investigating judge is associated with the protection of the right to fair trial. The fairness of the court is assessed also after the formation of the composition of the court, and the fact that the judge in court has participated in prior proceedings means that the impartiality of the trial is compromised. In order to prevent this, part 3 and 4 of Section 52 of CPL prescribe that the investigating judge shall not be the person who has been the person directing the proceedings or supervising public prosecutor in the same criminal proceedings. A judge shall not participate in the adjudication of a case if he or she has participated in the criminal proceedings in any status. However, the legislation does not enshrine the prohibition for chairperson of the district or city court to carry out the functions of the investigating judge. In such cases problems may arise in connection with appealing the adjudication or the actions, as Section 337 of CPL prescribes that the complaint shall be examined by the chairperson of the court. The situation in which the person examining the complaint is also the very person who made the decision appealed against, is not permissible. It is worth noting that a different procedure is provided to appeal the implementation of compulsory measures related to the deprivation of liberty and in such situations complaints

80 Kriminālprocesa likuma projekta koncepcija. Latvijas Vēstnesis, 16.06.2001, 77(2474).

81 Kūtris G. Izmeklēšanas tiesneši - jauns institūts kriminālprocesā. Jurista vārds. 2006, Nr. 2, lpp. 1-4. 
in connection with the decisions of the investigating judge are examined by the judge of a higher lever court ${ }^{82}$.

One of the principles of criminal procedure states that there exists a segregation of procedural functions in accordance with which the function of controlling the restriction of human rights within the framework of pre-trial procedure is carried out by the investigating judge, which includes the compulsory measures within the jurisdiction provided by law. It is worth emphasizing that the investigating judge does not only carry out the aforementioned function in the course of pre-trial proceedings, but also, as enshrined in CPL, until the commencement of trial in the first instance court. Thus, for example, prior to the commencement of trial in the first instance court the investigating judge has to make a decision in connection with the selection or change of a security measure. It is essential to take into consideration the fact that, when carrying out his or her functions, the investigating judge must find sensible balance between the protection of human rights and the necessity of restricting the rights of an individual in the interests of maintaining public order.

Other restriction control functions mainly fall under the jurisdiction of the prosecutor. Therefore, it would be feasible to make Section 17 of CPL more specific so that it reads as follows: "The function of the control of restrictions of human rights in pre-trial proceedings and, in situations laid out in this law, until the commencement of trial in the first instance court, and the function of prosecution, defense, and court adjudication in criminal proceedings shall be separate”.

In the course of examining the suggestion for the implementation of arrest, the investigating judge must assess all the information at his or her

82 Kazaka S., Groma J. Izmeklēšanas tiesneša institūts kriminālprocesuālo piespiedu līdzekḷu aspektā // Administratīvā un kriminālā justīcija, ISSN 1407-2971, LZP Vispāratzīts recenzējamais zinātniskais izdevums, 1(58)/2012.g., lpp.10.-15. 
disposal (both that justifying the implementation of the measure and that challenging its necessity) in an absolutely unbiased and impartial manner, essentially evaluating all the facts for and against arrest in order to resolve the issue exclusively on the basis of legal criteria. External circumstances existing at the moment of making the decision concerning arrest are factors of paramount importance. Moreover, justifying the application of a security measure, it is permissible to extrapolate future behavior of the individual from the data obtained ${ }^{83}$. It is possible to conclude that the jurisdiction of the investigating judge is a complex body of functions, with exclusive nature inherent in some of those functions.

\subsection{The prevention of torture and inhuman or degrading treatment and the observation of the rights of persons deprived of their liberty in the course of the implementation of criminal procedural compulsory measures}

Although international human rights and humanitarian rules prohibit torture, both degrading treatment and torture are still practiced in half of the countries of the globe. This discrepancy between the complete prohibition of torture and its frequent occurrence in the world of today suggests that countries must establish and implement efficient measures in order to protect people from torture and degrading treatment. Efficient investigation and documentation of torture and other cruel inhuman or degrading treatment or punishment (Istanbul Protocol) is prescribed as an international guideline. The eradication of torture and other cruel inhuman or degrading treatment or punishment is an

83 Judins A., Kronberga I. Apcietinājums Latvijas kriminalprocesā // Providus, Rīga, 2011. www.politika.lv 
indispensable element of the EU human rights policy that is closely related to other EU activity domains and instruments ${ }^{84}$.

The member states are obliged to ensure prompt and efficient investigation of all allegations of torture and degrading treatment. It is worth noting that individuals in relation to whom the investigation is carried out must be able to enjoy the minimal procedural safeguards as laid out in international law. European Committee for the Prevention of Torture and Inhuman or Degrading Treatment or Punishment (hereinafter referred to as the Committee) has elaborated a set of criteria related to the treatment of persons who have been deprived of their liberty, and on the basis of the criteria the general standards are formulated. These are not only related to the material circumstances, but also to the procedural safeguards. For example, the procedural safeguards to be granted to detained individuals as proposed by the Committee are as follows: the right to inform relatives and other relevant third parties without delay about placement in detention as well as the right to have access to lawyers and medical care. It is important to emphasize the fact that ECHR has frequently addressed the issue of the necessity of investigating allegations of torture in order to ensure that the rights guaranteed by Article 3 of the Convention are observed. The first judgement in relation to this issue was rendered in the case of Aksoy v. Turkey ${ }^{85}$, when the court held that "where individual is taken into police custody in good health but found to be injured on release, incumbent on State to provide plausible explanation. Ill-treatment was of such a serious and cruel nature that it can only be described as torture, which

84 Eiropas Parlamenta Ārlietu komitejas 2014.gada 12.februāra ziņojums par spīdzināšanas izskaušanu pasaulē (2013/2169(INI)). http://www.europarl.europa. eu/sides/getDoc.do?pubRef=-//EP//TEXT+REPORT+A7-2014-0100+0+DOC+ $\mathrm{XML}+\mathrm{V} 0 / / \mathrm{LV} \#$ _part1_def1

85 Eiropas Cilvēktiesību tiesas spriedums lietā: Aksoy v. Turkey, judgement of 18 December 1996, application no. 21987/93, http://hudoc.echr.coe.int/sites/eng/ pages/search.aspx?i=001-58003\#\{"itemid":["001-58003"]\} 
is a violation of Article 3 of the Convention". According to the estimation of ECHR, ill-treatment has to achieve the minimum level of severity for it to fall within the scope of violation of Article 3 of the Convention. In the event of any treatment or punishment being classified as "inhuman" or "degrading", the suffering and abasement of human dignity have to by all means exceed this level, which is inevitably inherent in any legal action or punishment. The use of evidence obtained through a violation of one of the fundamental safeguards enshrined in the Convention - the absolute prohibition of torture - will always cast substantial doubt on the overall fairness of the trial. Thus, the implementation of evidence obtained through torture or inhuman treatment for the purpose of proving facts in issue in criminal proceedings essentially makes the whole process illegitimate. It would be sensible to emphasize the view expressed in Lithuanian jural literature highlighting the following principle in the context of evidentiary process: "whatever is laid out in law is permitted" In specific situations the ECHR examines complaints of sick persons in detention or under arrest concerning the accessibility of medical care, its rendering and quality. In assessing the availability of medical care to the person ECHR draws upon the data about the medical condition of the person, the availability of relevant medical aid and care, the practicality of the application of arrest taking into consideration the medical condition of the person. The violation of Article 3 of the Convention can be noted if a person needed continuing medical care which either was not rendered or was insufficient, which qualifies as inhuman and degrading treatment.

Taking into consideration the special meaning of the prohibition of torture and particular vulnerability of its victims, Article 13 of the Convention, notwithstanding any other domestic remedies, obliges the state to carry out a thorough and efficient investigation into any cases of torture as a result of

86 Ažubalytė R., Jurka R., Šalčius M., Zajančkauskienė J. Baudžiamojo proceso teisè. Mykolo Romerio Universitetas, 2014, Vilnius. - 274. 
which guilty persons must be found and punished ${ }^{87}$. The duty of the state to carry out investigations into every situation when there is an allegation of torture is enshrined in Article 12 of the UN Convention against Torture and Other Cruel, Inhuman or Degrading Treatment or Punishment ${ }^{88}$.

Already in 2003 the UN Committee against Torture recommended the ratification of the Optional Protocol (OPCAT) ${ }^{89}$ of the UN Convention against Torture and Other Cruel, Inhuman or Degrading Treatment or Punishment by Latvia and Lithuania. The preventive approach of the protocol is based on consistent and recurrent monitoring of places of deprivation of liberty by means of visits by experts in view of the fact that the common effort of member states in the sphere of violation prevention is more practical than public punishment for violations already committed. Even though the existing human rights instruments are aimed at constructive dialogue, they are still essentially meant to - either by notification or individual communication - ensure that the state fulfills its obligations. In compliance with OPCAT independent national and international preventive mechanisms must have dramatic impact facilitating the eradication of barbaric torture practices. In 2004 OPCAT was signed by Estonia, in 2014 it was ratified by Lithuania. However, the protocol still has not been ratified by Belgium, Ireland, Iceland, Slovakia, Finland

87 Eiropas Cilvēktiesību tiesas spriedums lietā: Rivière v. France, judgement of 11 July 2006, application no. 33834/03. http://hudoc.echr.coe.int/sites/eng-press/pages/ search.aspx?i=003-1732298-1816345\#\{"itemid":["003-1732298-1816345"]\}

88 Eiropas Cilvēktiesību tiesas spriedums lietā: Aydin v.Turkey, judgement of 25 September 1997, application no. 23178/94. http://hudoc.echr.coe.int/sites/eng/ pages/search.aspx?i=001-58371\#\{"itemid":["001-58371"]\}

89 See, for example, ANO Spīdzināšanas novēršanas konvencijas Papildprotokols: jaunu risinājumu laiks spīdzināšanas novēršanā Baltijas valstīs. Spīdzināšanas novēršanas asociācijas ziņojums. Rīga, Latvija, 2006.gada 27.-28.aprīlis. www. cilvektiesibas.org.lv/site/attachments/01/02/2012/OPCAT_LV.doc; Optional Protocol to the Convention against Torture and other Cruel, Inhuman or Degrading Treatment or Punishment. Adopted on 18 December 2002 at the fifty-seventh session of the General Assembly of the United Nations by resolution A/RES/57/199 entered into force on 22 June 2006. http://www.ohchr.org/EN/Profes sionalInterest/Pages/OPCAT.aspx 
and Latvia. The ratification of the protocol is closely connected with the establishment of the national mechanism of preventing torture and inhuman or degrading treatment. 


\section{CONCLUSIONS}

As a result of the research, having achieved the goal of the present dissertation and fulfilled the objectives, the author has reached the following conclusions:

1. Coercion is an indispensable element of any community structure; it affects the behavior of community members thus safeguarding legal order. It is a complex legal phenomenon and one of the characteristic traits of a state basing on the principle of the rule of law. A measure established in the law is the response to the assessment of legal facts by the state with an authorized institution affecting the behavior of community members with a view to safeguarding public order.

2. Criminal procedural compulsory measures are one of the types of compulsory measures implemented by the state. The main purpose of criminal procedural coercion is ensuring legal order as established by Criminal Procedure Law. Its social significance is characterized by the international standards of human rights protection and specific peculiarities of national law determining the implementation mechanism of criminal procedural compulsory measures. These are enshrined in Criminal Procedure Law and are applied by authorized state officials within their jurisdiction to participants in criminal proceedings aiming to influence their behavior as well as to facilitate the progress of criminal proceedings. No criminal procedural compulsory measure in itself is legally a penalty.

3. Resolving criminal procedural conflicts does not permit unreasonable restriction of human rights in the course of application of criminal procedural compulsory measures. The implementation of a criminal procedural compulsory measure is permissible providing the legal situation has arisen that the legislator has indicated as one providing grounds for the implementation of 
the compulsory measure, thus, the latter must be objectively justified. The restriction of human rights must be reasonable and proportional, but simultaneously sufficient to ensure particular procedural behavior of a person as laid out in CPL. In addition to the regulation of the basis for application of the compulsory measure the legislator established the whole of the implementation procedure. Moreover, there is a specific order of implementation for every criminal procedural compulsory measure. The application of procedural compulsory measures is connected with the restriction of human rights and fundamental freedoms within a particular period of time; the duration of the period of application of the compulsory measure is conditioned by the duration of the time span within which the grounds for application continue to exist. The selection of compulsory measures to be applied has to be proportional to the antisocial behavior of the person.

4. Fundamental human rights are institutionalized in both national and international legal norms establishing human right to liberty, physical integrity, the right to not be subjected to torture, the right to legal aid and fair trial, etc. Human rights are recognized and declared as core values. The implementation of criminal procedural compulsory measures is always connected with certain limitation of the constitutional rights of a person; it can curtail the freedom of a person, property rights, social rights, the right to the freedom of movement and residence, the right to choose occupation, the right to communication, the freedom of choice, etc. In restricting the fundamental rights of a person public authority must maintain sensible balance between public and individual interests.

5. The right to control the observation of human rights in criminal proceedings is given to the investigating judge within the framework of his or her own jurisdiction; whereas other functions of control are assigned to the prosecutor. In compliance with Section 17 of CPL, the investigating judge does not only carry out the function of controlling the observation of human 
rights in the course of pre-trial proceedings, but also (in particular cases specified by law) until the commencement of trial in the first instance court.

6. The contemporary institute of criminal procedural compulsory measures is characterized by liberalization and humanistic approach that is reflected in reducing procedural repression and adequate application of the aforementioned measures. The existence of a wide range of criminal procedural compulsory measures and the expansion thereof by means of introducing additional less intrusive compulsory measures is an indication of this.

7. Admitting the fact that in Latvia a regular criminal procedure is considered to be the fundamental form, the implementation of a simplified criminal procedure means the application of a contemporary approach widely practiced in European countries for the purpose of considerably accelerating the progress of criminal proceedings. This helps optimize the operation of law enforcement institutions as well as save time and resources. This differentiated approach to criminal proceedings does not indicate a lack of legitimacy, but, quite contrarily, helps achieve the fundamental purpose of the criminal procedure in a practical and resource-efficient way.

8. The procedural compulsory measures established in criminal procedural norms constitute a system which is a body of structured elements with every individual element still preserving its relative autonomy. Special legal literature contains different views considering the classification of criminal procedural compulsory measures and its criteria, the set of the latter including the purpose of application, the nature of the offence, the extent of intensity, the extent of liberty restriction, the person subjected to it, etc., however, in Criminal Procedural Law the measures are classified to fall into the following two categories - those related to the deprivation of liberty and those not related to the deprivation of liberty. In terms of criminal procedural measure classification criteria though, the following classifications have the right to exist: the classification according to the authorized official/institution 
implementing the security measure (the person directing the proceedings, the investigating judge, the court), the possibility of appeal (the security measures that can be made subject to appeal altogether or in relation to the restrictions imposed).

9. Since the moment CPL came into force the legislator has been using the generalized approach to legal regulation in determining the reason for the implementation of criminal procedural compulsory measures, which has been subject to continuous polemic among legal science professionals.

10. The Convention institutionalizes fundamental human rights and provides the basis for establishing the mechanism of protection thereof. The ECHR judicature interpreting the legal norms of the Convention has considerable impact on the legal acts and court practice of all the member states. Within the period of time from 1997 to 2014246 cases against Latvia were reviewed by ECHR. Moreover, the violation of Article 5 of the Convention (i.e. the violation of rights to liberty and security) was found to be increased in 2014 when compared to 2013 constituting the second major category of cases. It is essential to ensure that the imlpementation of procedural compulsory measures complies with the standards laid out in the Convention.

11. According to ECHR, "reasonable suspicion" is the existence of a fact or information that is capable of convincing any person otherwise not involved in the proceedings that the person involved might have committed the criminal offence.

12. In the event of deprivation of liberty the court must automatically control the situation regardless of whether it has been requested by the person. The feasibility of further implementation of detention must be well justified; the initial suspicion of a person must never be the only reason for further implementation of detention. The duration of arrest must have other justifications than the severity of the offence committed. It is worth noting that considering past experience according to ECHR recurring problems were noted 
in the sphere of implementation of the security measure of detention within the period from 1998 to 2000 (ECHR Cernikovs v. Latvia case). Public interests and the significance of individual liberty of a person must be assessed individually in every case. Basing on ECHR judgements, it is possible to conclude that the period of detention is not an abstract category, and the national court must make sure that the period of detention is no longer than is necessary. In recent years national courts have considerably improved their awareness of ECHR standards, the issues related to the implementation and prolongation of detention with formal approach being substituted for a motivated assessment taking into considerations the specific circumstances of every case.

13. Common international efforts in the sphere of criminal law and criminal procedures are part of international cooperation, facilitating which is one of the principles of further development of EU member states. It is essential for countries cooperating in their anti-criminal effort to achieve a sensible balance between efficiency and reliable procedural guarantees.

14. The instruments related to the deprivation of liberty can be implemented in international cooperation in the sphere of criminal law. Measures related to the deprivation of liberty must be used in order to facilitate criminal prosecution for serious offences that cause considerable damage and by all means justify the application of these measures as well as to execute sentences. European Arrest Warrant is a judicial instrument that is based upon the on the principle of mutual recognition, which is issued with the requirement for another member state to arrest and transfer a criminal suspect or sentenced person to the issuing state so that the person can be put on trial or complete a detention period.

15. The transference and adjustment of the principle of mutual recognition, that was initially established in the sphere of sales as one of the fundamental principles facilitating free movement of goods and services, to the 
sphere of criminal law is rather controversial, as aiming to achieve the principal goal of a criminal procedure and ensure the impartiality of the trial involves a high risk of fundamental human rights being violated. The existence of similar standards in all the EU member states in relation to the pre-trial criminal procedure and the procedural safeguards available in it is only a presupposition; moreover, the regulation of detention and its conditions in EU member states vary. A predictable situation may arise when a person is sent to a state the language of which the person does not understand and where the person might potentially have to spend a long time without any access to any legal remedies that would allow to change the security measure applied and without the possibility of communicating with relatives as well as without any legal aid. The problem is particularly topical if the EU member state considered already has certain negative background in connection with cases reviewed by ECHR concerning the violation of Article 3, 5 and 6 of the Convention. The further harmonization of legal acts regulating the sphere of justice and home affairs that provide grounds for making the EU a place ruled by law, freedom and security, facilitates the enhancement of cooperation in the sphere of criminal proceedings.

16. The eradication of torture is an indispensable element of the EU human rights policy that is closely related to other EU activity domains and instruments. The prevention of torture and inhuman or degrading treatment in relation to persons deprived of their liberty in the course of the implementation of criminal procedural compulsory measures related to the deprivation of liberty is an issue of primary importance. The ratification of the Optional Protocol (OPCAT) of the UN Convention against Torture and Other Cruel, Inhuman or Degrading Treatment or Punishment by Latvia would provide the basis for the establishment of the national mechanism of preventing torture and inhuman or degrading treatment. 
Apart from proposals made in the body and summary of the thesis the author brings forward the following major proposals for defense and offers to adopt the following amendments to a Criminal Procedure Law:

1. Immunity from Criminal proceedings is one of the fundamental principles defined in CPL, in accordance with which among other advantages application of criminal procedural compulsory measures is prohibited or restricted concerning immunity enjoying persons. Notwithstanding, The Constitutional Court judge is not specified in CPL as a State Official enjoying immunity from criminal proceedings. Since the Constitutional Court Law and CPL are lacking legal regulation determining the action if a Constitutional Court judge has been apprehended in the committing of a serious or especially serious crime, the author offers to amend Section 120, paragraph 2 of CPL specifying the action concerning a Constitutional Court judge similarly a judge or ombudsman.

2. Legal regulation of CPL in force determines that a decision not being necessary under other circumstances should be made regarding detention of immunity enjoying person. Hereto, adoption of decision regarding an urgent detention made when a serious or especially serious crime is committed shall not be necessary. These grounds allow putting forward a proposal to supplement Section 263 of CPL with the following sentence to provide as follows: „In the cases stipulated by CPL a decision should be made regarding the detention of a State Official enjoying immunity from criminal proceedings".

3. Taking into consideration that the supervisory power in criminal proceedings is given not only to a person directing the proceedings, but to a member of an investigative group, supervising prosecutor, executor of procedural tasks and immediate superior of investigator as well, the author offers to amend Section 250, paragraph 1 of the CPL 
so that it reads as follows: "If a person does not arrive without a justifying reason at a procedural action on the basis of a summons of an authorized official assigned to conduct the proceedings, conveyance by force may be applied by the authorized official within the framework of his or her own competence to such person in order to ensure the participation thereof in the procedural action".

4. Analysis of knowledge based on evaluation of ECHR judgments concerning understanding of the essence of the criminal procedural compulsory measure of conveyance by force and its influence on a person's liberty laid out in Article 5 of the Convention makes grounds to offer an amendment of Section 251, Paragraph 1 of CPL specifying that in the cases provided for it in the law, conveyance by force is applied only with a decision of investigating judge or court. Suggesting improvements of mechanism for Conveyance by Force the author puts forward a proposal to amend Section 251, Paragraph 1 and Section 251, Paragraph 3 of CPL to provide as follows: "Conveyance by force is applied with a decision of an authorized official assigned to conduct the proceedings that indicates who shall be conveyed, the official to whom such person shall be conveyed, and when and for what purpose such person shall be conveyed, as well as the police institution to which the conveyance by force has been assigned. Conveyance by force is applied only with a decision of investigating judge or court", and "If conveyance by force may not be applied, or if the person to be conveyed has not been found, a police employee shall record such fact in a decision, which shall be given to a person directing the proceedings or other authorized official who made a decision regarding conveyance by force“, accordingly.

5. The author offers to supplement CPL with Section $681^{1}$ so that it reads as follows: Compulsory measures related to the deprivation of liberty 
implemented in international cooperation in the criminal legal field. Enforcing international criminal cooperation rights of a person can be restricted applying the following criminal procedural compulsory measures:

1) detention of a person to be extradited to a European Union Member State;

2) detention of a person for the purpose of extradition;

3) arrest of a person to be extradited to a European Union Member State;

4) temporary arrest;

5) extradition arrest;

6) temporary arrest before the receipt of a request for a takeover of criminal proceedings;

7) temporary arrest after the receipt of a request for a takeover of criminal proceedings;

8) detention in order to decide a matter regarding temporary arrest;

9) detention of a person convicted in a foreign state;

10) temporary arrest of a person convicted in a foreign state;

11) detention of a person convicted in a European Union Member State;

12) temporary arrest of a person convicted in a European Union Member State.

In compliance with CPL a person to be extradited has no right to appeal in respect of decision regarding arrest; it leads to reduction of the procedural guarantees creating a different approach to the treatment of persons in criminal proceedings. In the context of aforementioned the author brings forward a proposal to regulate a right of the person to be extradited to appeal in respect of 
decision regarding arrest and amend Section 701, Paragraph 2 of CPL to provide as follows: "Having heard a public prosecutor, a person to be extradited, and a representative of defense, if he or she participates, a judge shall take a reasoned decision" as well as supplement CPL with Section 701, Paragraph $2^{1}$ providing it as follows: "A person to whom an arrest has been applied or a representative of defense may submit a complaint regarding a decision of an investigating judge within a term of seven days after the receipt of a copy of a decision taken regarding the application of such compulsory measure. The judge shall send his or her decision to a regional court together with the submitted complaint not later than the next working day".

The doctoral thesis is a complete scientific study. The goal of the study has been reached and the answers to the objectives formulated have been accomplished. Research questions of the doctoral thesis are fully approved. Using original approach the author of the thesis has analyzed the legal regulation of criminal procedural compulsory measures from the various points of view, namely, legal sociology, legal axiology, etc. accentuating a role of observation and proportionality of restriction of human rights in criminal proceedings as well as instruments implemented in international cooperation in the sphere of criminal legal field, and successfully identified attendant problems. 


\section{ACKNOWLEDGEMENTS}

I would like to acknowledge Professor Sandra Kaija for her supervision of my doctoral study and Thesis writing.

I would like to express sincere gratitude to the Dean of Faculty of Law, Riga Stradins University, Professor Andrejs Vilks for encouragement and support during my work on the doctoral Thesis.

I am very grateful to official reviewers Professor Vitolds Zahars, Professor Viktoras Justickis and Associate Professor Jānis Teivans-Treinovskis for suggestions and evaluation of the Thesis.

I am sincerely grateful to my family for understanding and support provided during my doctoral studies and writing of the Thesis. 


\section{LIST OF LITERATURE AND SOURCES}

1. Acker J.R., Brody D.C. Criminal procedure. - 2013. $3^{\text {rd }}$ ed., $-1-672$ p. http://www.amazon.com/Criminal-Procedure-A-Contemporary-

Perspective/dp/1449652344\#reader_1449652344

2. ANO Spīdzināšanas novēršanas konvencijas Papildprotokols: jaunu risinājumu laiks spīdzināšanas novēršanā Baltijas valstīs. Spīdzināšanas novēršanas asociācijas ziņojums. Rīga, Latvija, 2006.gada 27.-28.aprīlis. www. cilvektiesibas.org.lv/ site/attachments/01/02/2012/OPCAT_LV.doc

3. Ažubalytė R., Jurka R., Šalčius M., Zajančkauskienė J. Baudžiamojo proceso teisè. Mykolo Romerio Universitetas, 2014, Vilnius. - 274.

4. Berezins A. Apcietinājuma institūta teorētiskās un prakstiskās problēmas // Jurista Vārds, 2012, Nr. 13 (712), 21. lpp.

5. Bogdan M. Comparative Law. Kluwer Law and Taxation Publishers. $-1^{\text {st }}$ edition, 1994, 30-32 pp.

6. Convention for the Protection of Human Rights and Fundamental Freedoms as amended by Protocols No.11 and No.14. http://conventions.coe.int/treaty/en/ treaties/html/005.htm

7. Dundure L. Izmeklēšanas tiesnesis Latvijā. // Jurista Vārds, 2012, 17/18(716/717): 26.-31. lpp.

8. Dzīvesvietas deklarēšanas likums. Latvijas Republikas likums ("LV", 104 (2679), 08.07.2002.; Ziņotājs, 16, 22.08.2002.) [stājas spēkā 01.07.2003.] ar grozījumiem.

9. Eiropas Cilvēktiesību tiesas spriedums lietā Lelièvre v. Belgium, judgement of 8 November 2007, application no.11287/03. http://sim.law.uu.nl/sIm/CaseLaw/hof. nsf/2422ec00f1ace923c1256681002b47f1/c6ece051f116f4ffc1257386003bd3d2?Op enDocument

10. Eiropas Cilvēktiesību tiesas spriedums lietā: Aydin v.Turkey, judgement of 25 September 1997, application no.23178/94. http://hudoc.echr.coe.int/sites/eng/pages/ search.aspx?i=001-58371\#\{"itemid":["001-58371"]\}

11. Eiropas Cilvēktiesību tiesas spriedums lietā: Aksoy v. Turkey, judgement of 18 December 1996, application no.21987/93, http://hudoc.echr.coe.int/sites/eng/pages/ search.aspx?i=001-58003\#\{"itemid":["001-58003"]

12. Eiropas Cilvēktiesību tiesas spriedums lietā: Ambruszkiewicz v. Poland, judgement of 23 October 2006, application no.38797/03. http://hudoc.echr.coe.int/sites/fra/ pages/search.aspx\#\{"languageisocode":["FRA"],"itemid":["001-75344"]\}

13. Eiropas Cilvēktiesību tiesas spriedums lietā: Amuur v. France, judgement of 25 June 1996, application no.19776/92, http://hudoc.echr.coe.int/sites/eng/pages/search. aspx\#\{"appno":["19776/92"]\}Eiropas Cilvēktiesību tiesas spriedums lietā: Brogan and others $v$. the United Kingdom, judgement of 29 November 1988, application no.11209/84; 11234/84; 11266/84; 11386/85, http://hudoc.echr.coe.int/sites/eng/ pages/search.aspx?i=001-57450\#\{"itemid":["001-57450"]\}

14. Eiropas Cilvēktiesību tiesas spriedums lietā: De Wilde, Ooms and Versyp ("Vagrancy") v. Belgium, judgment of 18 June 1971, application no.2832/66; 2835/66; 2899/66. http://hudoc.echr.coe.int/sites/eng/pages/search.aspx?i=00157606\#\{ "itemid":["001-57606"]\}

15. Eiropas Cilvēktiesību tiesas spriedums lietā: Estrikh v. Latvia, judgement of 18 January 2007, application no.73819/01. http://sim.law.uu.nl/SIM/CaseLaw/hof. 
nsf/233813e697620022c1256864005232b7/0ca9c88419c27167c125726c00345d00?

OpenDocument

16. Eiropas Cilvēktiesību tiesas spriedums lietā: Foka v. Turkey, judgment of 24 June 2008, application no.28940/95, para 78. http://hudoc.echr.coe.int/sites/eng/pages/ search.aspx?i=00187175\#\{"itemid":["001-87175"]\}

17. Eiropas Cilvēktiesību tiesas spriedums lietā: Garcia Alva v. Germany, judgement of 13 February 2001, application no.23541/94. http://hudoc.echr.coe.int/sites/eng/ pages/search.aspx?i=001-59208\#\{"itemid":["001-59208"]\}

18. Eiropas Cilvēktiesību tiesas spriedums lietā: Idalov v. Russia, judgement of 22 May 2012, application no.5826/03. http://hudoc.echr.coe.int/sites/eng/pages/search. aspx?i=001-110986\#\{"itemid":["001-110986"]\}.

19. Eiropas Cilvēktiesību tiesas spriedums lietā: Khudoyorov v. Russia, judgement of 12 April 2006, application no.6847/02. http://hudoc.echr.coe.int/sites/eng/pages/search. aspx?i=001-70865\#\{"itemid":["001-70865"]\}

20. Eiropas Cilvēktiesību tiesas spriedums lietā: Lavents v. Latvia, judgement of 28 November 2002, application no.58442/00, http://sim.law.uu.nl/sim/caselaw/Hof.nsf/ 1d4d0dd240bfee7ec12568490035df05/e39a38852cec221d41256c800045eb6e?Open Document

21. Eiropas Cilvēktiesību tiesas spriedums lietā: Lavents v. Latvia, judgement of 28 November 2002, application no.58442/00. http://sim.law.uu.nl/sim/caselaw/Hof.nsf/ 1d4d0dd240bfee7ec12568490035df05/e39a38852cec221d41256c800045eb6e?Open Document

22. Eiropas Cilvēktiesību tiesas spriedums lietā: Mancini v. Italy, judgement of 2 August 2001, application no.44955/98. http://hudoc.echr.coe.int/sites/eng/pages/ search.aspx?i=001-59626\#\{"itemid":["001-59626"]\}

23. Eiropas Cilvēktiesību tiesas spriedums lietā: McKay v. the United Kingdom, judgement of 3 October 2006, application no.543/03, http://hudoc.echr.coe.int/sites/ eng/pages/search.aspx ?i=001-77177

24. Eiropas Cilvēktiesību tiesas spriedums lietā: Meloni v. Switzerland, judgement of 10 July 2008, application no.61697/00. http://hudoc.echr.coe.int/sites/fra/pages/ search.aspx\#\{"itemid":["001-85776"]\}

25. Eiropas Cilvēktiesību tiesas spriedums lietā: Michta v. Poland, judgement of 4 May 2006, application no.13425/02, http://sim.law.uu.nl/sim/caselaw/Hof.nsf/ 1d4d0dd240bfee7ec12568490035df05/56c9c49b5a9f466ec125716100418250?Open Document

26. Eiropas Cilvēktiesību tiesas spriedums lietā: Nikolova v. Bulgaria, judgement of 25 March 1999, application no.31195/96. http://hudoc.echr.coe.int/sites/eng/pages/ search.aspx?i=001-58228\#\{"itemid":["001-58228"]\}

27. Eiropas Cilvēktiesību tiesas spriedums lietā: Pélissier and Sassi v. France, judgement of 25 March 1999, application no. 25444/94,http://hudoc.echr.coe.int/ sites/eng/pages/search.aspx?i=001-58226\#\{"itemid":["001-58226"]\}

28. Eiropas Cilvēktiesību tiesas spriedums lietā: Piechowicz v. Poland, judgement of 17 April 2012, application no.20071/07, http://www.tiesibsargs.lv/files/content/ spriedumi/Pjehovics\%20pret\%20Poliju\%20\%28Piechowicz\%20v.\%20Poland\% 29.pdf

29. Eiropas Cilvēktiesību tiesas spriedums lietā: Piruzyan v. Armenia, judgement of 26 June 2012, application no.33376/07. http://sim.law.uu.nl/SIM/CaseLaw/hof. 
nsf/d0cd2c2c444d8d94c12567c2002de990/bd5e02e2a1b3d224c1257a22003f916e?

OpenDocument

30. Eiropas Cilvēktiesību tiesas spriedums lietā: Rivière v. France, judgement of 11 July 2006, application no.33834/03. http://hudoc.echr.coe.int/sites/eng-press/pages/ search.aspx?i=003-1732298-1816345\#\{"itemid":["003-1732298-1816345"]\}

31. Eiropas Cilvēktiesību tiesas spriedums lietā: S.B.C. v. the United Kingdom, judgement of 19 June 2001, application no.39360/98. http://sim.law.uu. nl/SIM/CaseLaw/hof.nsf/d0cd2c2c444d8d94c12567c2002de990/cc6235da654fd924 c1256a7100366ced?OpenDocument

32. Eiropas Cilvēktiesību tiesas spriedums lietā: the Lamy v. Belgium, judgment of 30 March 1989, Series A no. 151, § 27, application no.10444/83, www.Echr.coe.int/Documents/Stats_violation_1959_2012_ENG.pdf

33. Eiropas Cilvēktiesību tiesas spriedums lietā: the Lamy v. Belgium, judgment of 30 March 1989, Series A no. 151, § 27, application no.10444/83. www.Echr.coe.int/Documents/Stats_violation_1959_2012_ENG.pdf

34. Eiropas Cilvēktiesību tiesas spriedums lietā: Vrenčev v. Serbia, judgement of 23 September 2008, application no.2361/05. http://hudoc.echr.coe.int/sites/eng/ pages/search.aspx?i=001-88554\#\{"itemid":["001-88554"]\}

35. Eiropas Cilvēktiesību tiesas spriedumus lietā: Luluev and Others v Russia, judgment of 9 November 2006, application no.69480/01, para $\$ 122$. 350, http://www.srji.org/resources/search/52/

36. Eiropas Cilvēktiesību tiesas spriedumus lietā: Cicek v. Turkey, judgment of 27 february 2001, application no.25704/94, para 164, http://echr.ketse.com/doc/ 25704.94-en-20010227/

37. Eiropas Parlamenta Ārlietu komitejas 2014.gada 12.februāra ziņojums par spīdzināšanas izskaušanu pasaulē (2013/2169(INI)). http://www.europarl. europa.eu/sides/getDoc.do?pubRef=-//EP//TEXT+REPORT+A7-20140100+0+DOC+XML+V0//LV\#_part1_def1

38. Eiropas Parlamenta un Padomes Direktīva 2010/64/ES (2010. gada 20. oktobris) par tiesībām uz mutisko un rakstisko tulkojumu kriminālprocesā. ES Oficiālais Vēstnesis L 280. 26.10.2010. http://eur-lex.europa.eu/legal-content/LV/TXT/ ?uri=OJ:L:2010:280:TOC

39. Eiropas Savienības Padomes 2969. Sanāksmes paziņojums presei 14936/09 (Presse 306),23.10.2009.//http://www.google.lv/url?sa=t\&rct=j\&q=\&esrc=s\&source=web\& $\mathrm{cd}=8 \&$ ved=0CGQQFjAH\&url=http $\% 3 \mathrm{~A} \% 2 \mathrm{~F} \% 2$ Feuropa.eu $\% 2$ Frapid $\% 2$ Fpressrelease_PRES-09-

306_lv.doc\&ei=VooIVOH3O4b8ygORg4GACw\&usg=AFQjCNHdqF_dil9sCGbDqIImaVxuwsiTQ\&sig2=35aR_58qaujFPAL1ZOW9zg\&bvm=bv.74649129,d.bGQ

40. European Court of Human Rights Finds Violations of the European Human Rights Convention in German Pre-trial Detention Procedures. German Law Journal. http://www.germanlawjournal.com/article.php?id=56

41. Gabrāns M. Aizturētas personas tiesību zināt aizturēšanas iemeslu analīze // Transformācijas process tiesībās, regiionālajā ekonomikā un ekonomiskajā politikā: ekonomiski-politisko un tiesisko attiecību aktuālās problēmas. II Starptautiskās zinātniski praktiskās konferences rakstu krājums. - Rīga, - 2014, 55.-60.lpp.

42. Gailīte V. Izmeklēšanas tiesneša kompetence. // Jurista Vārds, 2006, Nr. 7(410). 
43. Kazaka S., Groma J. Izmeklēšanas tiesneša institūts kriminālprocesuālo piespiedu līdzekḷu aspektā // Administratīvā un kriminālā justīcija, ISSN 1407-2971, LZP Vispāratzīts recenzējamais zinātniskais izdevums, 1(58)/2012.g., 10.-15. lpp.

44. Grozījumi Kriminālprocesa likumā. Latvijas Republikas likums („LV”, 92 (4695), 13.06.2012.;) [stājas spēkā 01.07.2012.].

45. Iljanova D. Vispārējo tiesību principu nozīme un piemērošana. Rīga, Nodibinājums Ratio iuris, 2005, 57.-58. lpp.

46. Informatīvais ziņojums par 2014. gada 23.-24. janvārī neformālajā Eiropas Savienības Tieslietu un iekšlietu ministru padomē izskatāmajiem Tieslietu ministrijas kompetencē esošajiem jautājumiem. www.mk.gov.lv/doc/2005/ TMZino_200114_JHAC.127.doc

47. Intervija: Nedēḷas jurists - Inga Reine, Jurista Vārds, 2010, Nr. 24, 2. lpp.

48. Judins A. Ar brīvības atņemšanu nesaistītie drošības līdzekḷi. - Rīga: Providus, 2008. - lpp. 76.

49. Judins A. Ar brīvības atņemšanu nesaistītie drošības līdzekḷi. Rīga, 2008, lpp. 10.

50. Judins A. Atjaunojošā Justīcija nepilngadīgo noziedzības kontekstā: Baltijas valstis Eiropas dimensijā. Rīga: Providus, 2010. http://at.gov.lv/files/uploads/files/docs/ 2011/atjaunojosa\%20justicija.pdf

51. Judins A., Kronberga I. Apcietinājums Latvijas kriminālprocesā // Providus, Rīga, 2011. www.politika.lv

52. Kaija S. Aktuālākie transformācijas virzieni kriminālprocesa tiesību jomā Latvijā // Administratīvā un Kriminālā Justīcija, 2013, Nr.1, 15.-20. lpp.

53. Kaija S. Kriminālprocesa tiesību transformācija Latvijā. Transformācijas process tiesībās, reǵionālajā ekonomikā un ekonomiskajā politikā. Rīga, 2013, 39.-47. lpp.

54. Kazaka S., Groma J. Piespiedu līdzekḷu ietekme uz konflikta risināšanu kriminālprocesā. Administratīvā un Kriminālā Justīcija, 2012; 2 (59): lpp. 28.

55. Kegley, J.A.K.. Re-assessing Compulsion and Persuation in Democracy via a New Framework // J. A. K. Kegley and K. P. Skowronski (Eds.), Persuasion and Compulsion in Democracy. - 2013, - Lexington Books, Plymouth, UK, 1-18 pp.

56. Kēnigs M. Cilvēktiesības. Rīga, TNA, 2010., 41. lpp.

57. Kriminālprocesa likuma projekta koncepcija. Latvijas Vēstnesis, 16.06.2001, 77(2474).

58. Krimināltiesības - attīstības tendences Eiropas un nacionālajā tiesībās, attiecības starp I un III pīlāru, ieviešanas metožu labākā prakse. Rīga, 2009. //http:www.tm.gov.lv/documents/petijumi/kriminaltiesibas2.doc

59. Kūtris G. Izmeklēšanas tiesneši - jauns institūts kriminālprocesā. // Jurista Vārds. 2006, Nr. 2(405), lpp. 1-4.

60. Latvijas pārstāvja starptautiskajās cilvēktiesību institūcijās darba pārskats par 2013.gadu // http://www.mfa.gov.lv/parskats_2013.pdf

61. Latvijas Republikas Augstākās tiesas Senāta Krimināllietu departamenta 2012. gada 22. marta lēmums lietā Nr. SKK-193/2012, Jurista vārds, 2012, Nr.25(724), 30. lpp.

62. Latvijas Republikas Ministru kabineta 17.08.2012. vēstule Nr. 18/TA-664. tap.mk.gov.lv/doc/2005/VMinfo_270712_Saeima.664.docx

63. Latvijas Republikas Satversmes komentāri; VIII nodaļa, Cilvēka pamattiesības, sagatavojis autoru kolektīvs R. Baloža vadība, Latvijas Vēstnesis, 2011. http://home.lu.lv/ rbalodis/Publikacijas/Constitutional_Law/Satv_Kom_ievads_R. Balodis.pdf 
64. Latvijas Republikas Satversmes tiesas 2000. gada 24. marta spriedums lietā Nr.0407(99) // www.satv.tiesa.gov.lv/upload/04-07(99).rtf

65. Levits E. Latvijas tiesību sistēmas attīstības iezīmes uz XXI gadsimta sliekšņa. Grām.: Latvijas tiesību vēsture (1914-2000). Prof. Dr.iur. D.A. Lēbera redakcijā. Rīga: LU žurnāla „Latvijas Vēsture” fonds, 2000., 493. lpp.

66. Līguma par Eiropas Savienību konsolidētā versija. Eiropas Savienības Oficiālais Vēstnesis, C 83/13, 30.03.2010., erv/LexUriServ.do?uri=OJ:C:2010:083: 0047:020:lv:PDF

67. Meikališa Ā. Drošības līdzekḷu kriminālprocesuālā reglamentācija Latvijas likumdošanā. Rīga, 1995, 5.-44. lpp.

68. Meikališa Ā, Strada - Rozenberga K. Pārmaiņu laiks kriminālprocesā. Procesuālie piespiedu līdzekļi un sankcijas // Jurista Vārds, 2006; 26: 11. 1pp.

69. Meikališa Ā. Kriminālprocesuālo piespiedu līdzekḷu piemērošanas mehānisms kriminālprocesā // Zinātniski praktiskās konferences "Latvijas Kriminālprocesa likuma piemērošanas pirmā gada problēmas'materiāli. Rīga, LPA, 2006., 147.152. lpp.

70. Meikališa Ā. Pārskats par kriminālprocesa attīstību Latvijā 2005.-2011. gadā // LZA Vēstis, 2012/66: 76.-80. lpp.

71. Melderis J. Vērtību teorijas un NBS pamatvērtības. Militāri zinātnisks žurnāls „Militārā zinātne”, 2011, 1, 141. lpp.

72. Mits M. Eiropas Savienības prasības cilvēktiesību jomā - strap mājas darbiem un brīvlaiku Latvijā. Eiropas Savienība un tiesiska valsts: Latvijas pieredze, Rīgas Juridiskā augstskola. - Rīga, 2009, 70.-85. lpp.

73. Murdoch J. Protecting the right to freedom of thought, conscience and religion under the European Convention on Human Rights. Council of Europe, Strasbourg, 2012, http://www.coe.int/t/dghl/cooperation/capacitybuilding/Source/documentation/hb09 _rightfreedom_en.pdf

74. Nevera A. Impositon and extension of detention: standards of the European Court of Human Rights and Lithuania's practice. // Administratīvā un Kriminālā Justīcija, 2013, Nr.3(64), 48.-58. lpp.

75. Optional Protocol to the Convention against Torture and other Cruel, Inhuman or Degrading Treatment or Punishment. Adopted on 18 December 2002 at the fiftyseventh session of the General Assembly of the United Nations by resolution A/RES/57/199 entered into force on 22 June 2006. http://www.ohchr.org/ EN/ProfessionalInterest/Pages/OPCAT.aspx

76. Padomes Rezolūcija 2009/C 295/01 par cel̦vedi aizdomās turētu vai apsūdzētu personu procesuālo tiesību stiprināšanai kriminālprocesā. 30.11.2009. ES Oficiālais Vēstnesis C 295. 04.12.2009. http://eur-lex.europa.eu/legal-content/LV/TXT/; ELX_SESSIONID=y1hTTkcWDfvzP4MnK6dGGcr8N1nTNYv70khC7p5JmBylB8 Z2Lnqs!760646899?uri=OJ

77. Recommendation No.R(92) 16 of the Committee of Ministers to member states on the European rules on community sanctions and measures// http://pjpeu.coe.int/documents/3983922/6970334/CMRec+(92)+16+on+the+European+rules +on+community+sanctions+and+measures.pdf/01647732-1cf7-4ea8-88ba2c041bc3f5d6

78. Recommendation No.R(92)16 of the Committee of Ministers to member states on the European rules on community sanctions and measures// http://pjp- 
eu.coe.int/documents/3983922/6970334/CMRec+(92)+16+on+the+European+rules +on+community+sanctions+and+measures.pdf/01647732-1cf7-4ea8-88ba2c041bc3f5d6

79. Recommendation $\operatorname{Rec}(2000) 22$ of the Commitee of Ministers to member states on improving the implementation of the European rules on community sanctions and measures (Adopted by the Commitee of Ministers on 29 November 2000 at the $731^{\text {st }}$ meeting of the Ministers Deputies) // https://wcd.coe.int/com.instranet.Instra Servlet?command=com.instranet.CmdBlobGet\&InstranetImage=534373\&SecMode $=1 \&$ DocId $=377888 \&$ Usage $=2$

80. Roagna I. Protecting the right to respect for provate and family life under the European Convention on Human Rights. Council of Europe, Strasbourg, 2012, http://www.coe.int/t/dghl/cooperation/capacitybuilding/Source/documentation/hb11 _privatelife_en.pdf

81. Skaidrojošā vārdnīca. http://www.tezaurs.lv/sv/?w=vieta

82. Skrastiņš J. Par jauniem likuma pamatprincipiem // Jurista Vārds, 2001; (7).

83. Sluiter G. International Criminal Procedure. Rules and Principles // G. Sluiter, H. Friman, S. Linton, S. Zappala, S. Vasiliev (Eds.). - 2013, - Oxford University Press, Oxford, 1-1681. pp.

84. Strada - Rozenberga K. Kriminālprocesa vienkāršošana: izpratne, tendences, problēmas // Jurista Vārds, 2004; (30).

85. Strada-Rozenberga K. Tiesu darbam aktuālākais 2012. gada 24. maija kriminālprocesa likuma grozījumos // Augstākās tiesas biḷetens, 2013, 6: 73.-81. lpp. http://at.gov.lv/files/uploads/files/docs/2013/ATBiletens6_web.pdf

86. Vilks A. Krimināltiesiskā politika: diskursa analīze un attīstības perspektīvas. Rīga, Drukātava, 2013, 5. lpp.

87. Zahars V. Kriminālpolitika: mūsdienu tendences un procesi. - Daugavpils Universitātes Akadēmiskais apgāds ,Saule”, 2014, 7. lpp.

88. Ziemele I. (red.) Cilvēktiesības pasaulē un Latvijā. Izglītības soḷi, Rīga, 2000, 409. lpp.

89. Андреева О.И. Пределы ограничения прав личности в уголовном процессе. Вестник Томского государственного университета. Право, 2012, № 358. http://cyberleninka.ru/article/n/predely-ogranicheniya-prav-lichnosti-v-ugolovnomprotsesse\#ixzz2hyK124IV

90. Божьев В.П. Уголовный процесс. Москва, 2008., стр. 47.

91. Капинус Н.И. Процессуальные гарантии прав личности при применении мер пресечения в уголовном процессе: Монография. Москва, 2007, стр.12

92. Мельников В. Ю. Обеспечение и защита прав человека при применении мер процессуального принуждения в досудебном производстве Российской Федерации // Москва, 2014, 552 стр.

93. Петухова Т. Залог как мера пресечения // IV Starptautiskās jauno pētnieku un studentu zinātniski praktiskās konferences "Izaicinājumu un iespēju laiks: problēmas, risinājumi, perspektīvas" rakstu krājums, Rīga: 2014, 84.-88. lpp.

94. Рогов А.П. Правовое государство и государственное принуждение. Известия Саратовского университета, 2011, Т. II. Сер. Экономика. Управление. Право. Вып. 2, стр. 104-108. 
95. Смирнова И.Г. Права личности и аксиологическая сущность уголовного судопроизводства: постановка вопроса. Журнал Российское право в интернете. 2009 (05). www.rpi.msal.ru/prints

96. Стецовский Ю.И. Концепця судебной реформы и проблемы конституционной законности в уголовном судопроизводстве // Государство и право, 1993; (9): стр. 106.

97. Шевелева С.В. Уголовно-процессуальное принуждение, связанное с физическим воздействием, и гарантии его законности и обоснованности // Нижний Новгород, 2006, http://www.unn.ru/pages/disser/23.pdf

98. Шевелева С.В. Виды мер правового принуждения. Пробелы в российском законодательстве, 2010, 3, стр. 156 